\title{
Selected Legal and Institutional Issues Related to Ocean Thermal Energy Conversion (OTEC) Development
}

Ved P. Nanda
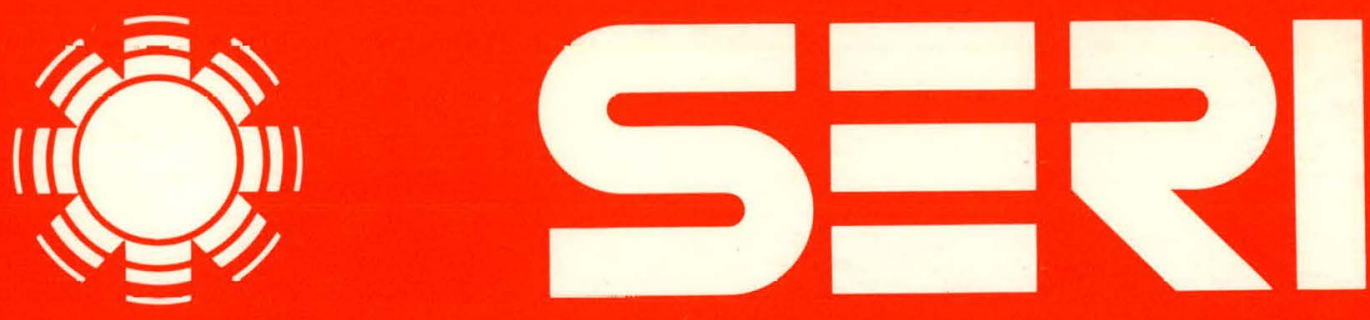

Solar Energy Research Institute A Division of Midwest Research Institute

1536 Cole Boulevard

Golden, Colorado 80401

Operated for the U.S. Department of Energy under Contract No. EG-77-C-01-4042 


\section{DISCLAIMER}

This report was prepared as an account of work sponsored by an agency of the United States Government. Neither the United States Government nor any agency Thereof, nor any of their employees, makes any warranty, express or implied, or assumes any legal liability or responsibility for the accuracy, completeness, or usefulness of any information, apparatus, product, or process disclosed, or represents that its use would not infringe privately owned rights. Reference herein to any specific commercial product, process, or service by trade name, trademark, manufacturer, or otherwise does not necessarily constitute or imply its endorsement, recommendation, or favoring by the United States Government or any agency thereof. The views and opinions of authors expressed herein do not necessarily state or reflect those of the United States Government or any agency thereof. 


\section{DISCLAIMER}

Portions of this document may be illegible in electronic image products. Images are produced from the best available original document. 
Printed in the United States of America

Available from:

National Technical Information Service

U.S. Department of Commerce

5285 Port Royal Road

Springfield, VA 22161

Frice:

Microfiche $\$ 3.00$

Printed Copy $\$ 5.25$

\section{NOTICE}

This report was prepared as an account of work sponsored by the United States Government. Neither the United States nor the United States Department of Energy, nor any of their employees, nor any of their contractors, subcontractors, or their employees, makes any warranty, express or implied, or assumes any legal liability or responsibility for the accuracy, completeness or usefulness of any information, apparatus, product or process disclosed, or represents that its use would not infringe privately owned rights. 
SERI / TR-62-204

UC CATEGORY: UC-64

SELECTED LEGAL AND INSTITUTIONAL ISSUES RELATED TO OCEAN THERMAL

ENERGY CONVERSION (OTEC) DEVELOPMENT -

VED P. NANDA

JUNE 1979

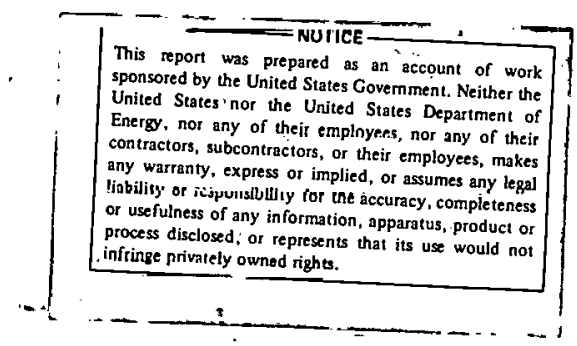

Solar Energy Research Institute

1536 Cole Boulevard

Golden, Colorado 80401

A Division of Midwest Research Institute

Prepared for the

U.S. Department of Energy

Contract No. EG.77.C.01.4012 


\section{FOREWORD}

This Ocean Thermal Energy Conversion (OTEC) Legal Reconnaissance Paper was prepared by the Solar Energy Research Institute (SERI) to fulfill, in part, SERI's solar information dissemination function. The paper is part of the Market Development Branch Law Program, which in turn is a part of the overall program of the Technology Commercialization Division.

This is the first of five Legal Reconnaissance Papers sponsored by the SERI Law Program. The other four address (1) legal issues surrounding the commercialization of wind energy conversion systems (WECS), (2) utilities and solar technologies, (3) municipal bonds as a method of accelerating public and municipal interest in solar energy, and (4) legal issues raised by the commercialization of solar heating and cooling (SHAC). These five studies are meant to survey broadly the legal questions that are raised by either a specific solar technology (i.e., OTEC, WECS, and SHAC) or a potential barrier or incentive to the general commercialization of solar technologies (i.e., utilities and municipal bonds). It is hoped that these reconnaissance papers will be springboards for further, more detailed studies of some aspect of the general topic covered.

The author of this paper, Ved Nanda, is a law professor and director of the International Legal Studies Program at the University of Denver College of Law. This report has also appeared in an adapted form as an article in the Denver Law Journal in 8 Denver J. of International Law and Policy 239 (1979).

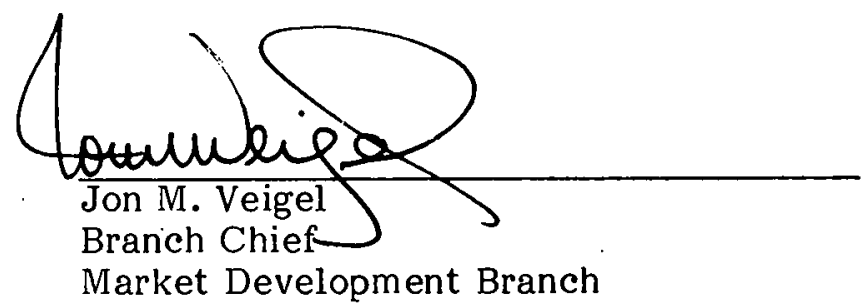

Approved for:

SOLAR ENERGY RESEARCH INSTITUTE

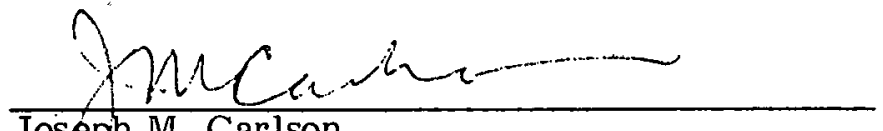

Joséph M. Carlson

Assigtant Director

Technology Commercialization Division 
TABLE OF CONTENTS

$\underline{\text { Page }}$

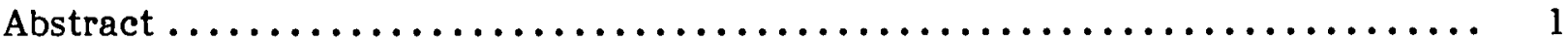

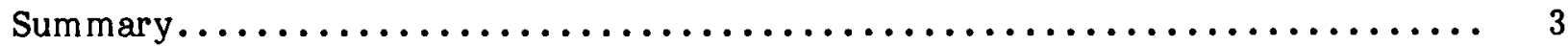

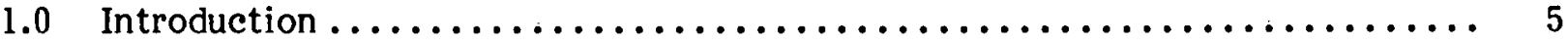

2.0 Jurisdictional, Regulatory, and Environmental Issues .............. 7

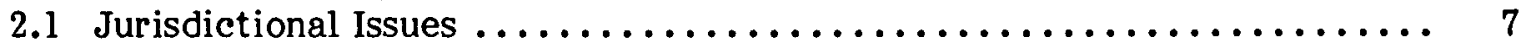

2.1.1 National-International Issues...................... 7

2.1.1.1 OTEC Devices under Traditional International

Law Regarding the Territorial Sea............. 8

2.1.1.2 OTEC Devices under the Emerging Law on the

Territorial Sea............................ 8

2.1.1.3 OTEC Devices on the Exclusive Economic Zone and the Continental Shelf .................. 8

2.1.1.4 OTEC Devices on the High Seas ................ 10

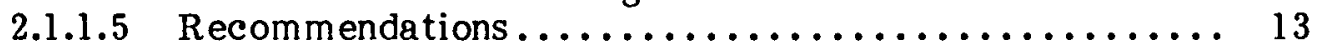

2.1.2 Federal-State Issues Related to OTEC Devices ................ 14

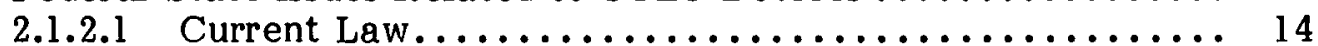

2.1.2.2 Federal-State Issues in Light of LOS III. ............ 17

2.1.2.3 Recommendations........................ 17

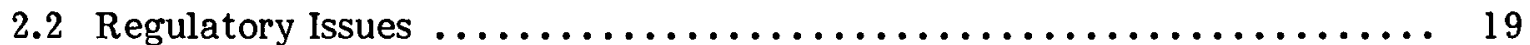

2.2.1 Legal Status of OTEC Devices ................... 19

2.2.2 International Regulatory Mechanisms and OTEC ........... 20

2.2.2.1 Current Law.............................. 20

2.2.2.2 Recommendations........................ 22

2.2.3 Federal-State Regulatory Mechanisms and OTEC ........... 23

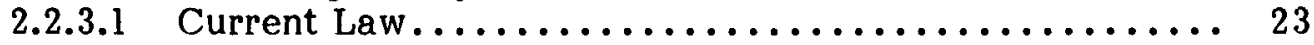

2.2.3.2 Recommendations........................ 25

2.3 Environmental Considerations...................... 26

2.3.1 Domestic (Federal-State) Issues . ................... 26

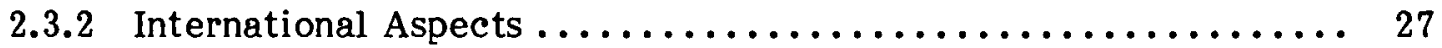

2.3.2.1 Unilateral U.S. Actions Related to the Marine

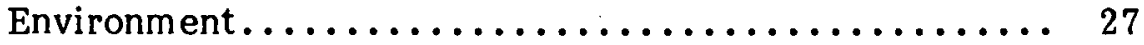

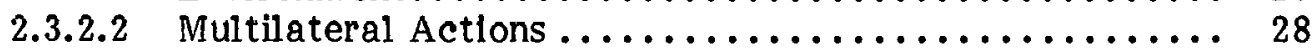

2.3.2.3 ICNT Provisions....................... 29

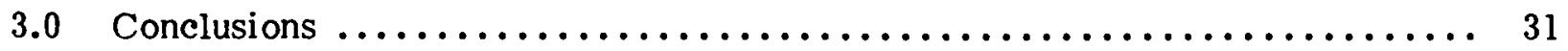

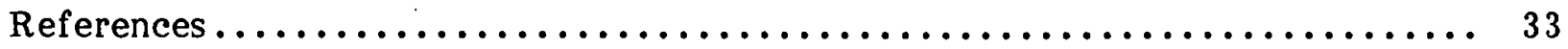




\begin{abstract}
Ocean Thermal Energy Conversion (OTEC), an attractive alternative to traditional energy sources, is still in the early stages of development. To facilitate OTEC commercialization, it is essential that a legal and institutional framework be designed now so as to resolve uncertainties related to OTEC development, primarily involving jurisdictional, regulatory, and environmental issues. The jurisdictional issues raised by OTEC use are dependent upon the site of an OTEC facility and its configuration; i.e., whether the plant is a semipermanent fixture located offshore or a migrating plant ship that provides a source of energy for industry at sea. These issues primarily involve the division of authority between the Federal Government and the individual coastal states. The regulatory issues raised are largely speculative: they involve the adaptation of existing mechanisms to OTEC operation. Finally, the environmental issues raised center around compliance with the National Environmental Policy Act (NEPA) as well as international agreements.
\end{abstract}


THIS PAGE INTENTIONALLY LEFT BLANK 


\section{SUMMARY}

Ocean Thermal Energy Conversion (OTEC), an attractive alternative to traditional energy sources, is still in the early stages of development. To facilitate OTEC commercialization, it is essential that a legal and institutional framework be designed now so as to resolve uncertainties related to OTEC development, primarily involving jurisdictional, regulatory, and environmental issues.

The jurisdictional issues raised by OTEC use are dependent upon the site of an OTEC facility and its configuration-i.e., whether the plant is a semipermanent fixture located offshore and connected to the shore by a transmission cable, or whether the facility is a migrating plant ship that provides a source of energy for industry at sea. The nationalinternational issues raised by OTEC plant location relate to jurisdiction over adjacent waters and in the high seas. The traditional law of the sea has undergone significant changes as a result of the ongoing Law of the Sea Conference (LOS III), which has produced an Informal Composite Negotiating Text (ICNT). These changes include the extension of the territorial sea, over which a nation state has exclusive jurisdiction, from the traditional three miles to 12 miles; the recognition of a contiguous zone which extends 24 miles; and an Exclusive Economic Zone (EEZ) which extends 200 miles from shore. The significance of the EEZ to OTEC devices is that ICNT grants the coastal state sovereign rights over the zone for the purpose of exploring for and exploiting natural resources. Also, a coastal state will have exclusive jurisdiction over the installation of any OTEC device located over its continental shelf. If the OTEC installation is located on the high seas, it may be subject to the jurisdiction of the proposed International Seabed Authority. At this stage of negotiations at LOS III, jurisdictional issues over the high seas have not been entirely resolved.

In the United States' coastal waters, the jurisdictional issues that arise relate to the division of authority between the Federal Government and the individual coastal states. A number of federal statutes, which have potential application to OTEC plants, attempt to delineate federal-state jurisdiction and powers in coastal zones. Such statutes include: the Submerged Lands Act, the Outer Continental Shelf Lands Act, the Deepwater Port Act, and the Coastal Zone Management Act. In light of the LOS III 12mile territorial waters, pertinent questions include: would coastal state jurisdiction also extend to 12 miles, or would the Federal Government preempt the states in energy matters? Who would be the licensing authority and what would be the licensing requirements?

The next area of concern to OTEC development relates to regulatory issues. In the international arena there does not yet exist any mechanism that would specifically regulate OTEC installations. However, it would be possible to adapt existing international conventions to various aspects of OTEC regulation. The conventions that could be used to regulate OTEC operation include the High Seas Convention and the Convention for the Prevention of Pollution from Ships. Also, a number of specialized U.N. agencies might exercise jurisdiction.

In the area of federal-state regulation, it will be necessary to develop a mechanism that is equitable in its reach while dealing with federal-state interests. The issues that require resolution pertain particularly to licensing and regulatory authority. The various aspects of OTEC regulation will most likely come under the authority of the Department of Energy/Federal Energy Regulatory Commission, the Coast Guard, and the Corps of Engineers. 
Finally, the environmental impact of OTEC development must be considered. Under domestic law, the National Environmental Policy Act (NEPA) requires Cederal agencies to file reports on the effects of federal actions which affect the environment. Since federal involvement in OTEC development will probably be substantial, it is likely that during the early stages of development, it will be necessary to file the applicable programmatic, regional, and site-specific Environmental Impact Statements.

There is also considerable international concern over the preservation of the environment. As a result, OTEC development may be subject to a number of international conventions, including the U.N. Declaration on the Human Environment, the London Convention on the Dumping of Wastes at Sea, the International Maritime Consultative Organization (IMCO) Convention on the Prevention of Pollution from Ships, and a number of provisions in the ICNT.

In conclusion, OTEC is a promising energy alternative that will require extensive technological research and development. In addition, both international and domestic legal frameworks should be evolved to meet the challenges that OTEC presents. 


\section{SECTION 1.0}

\section{NTRODUCTION *}

The discussion in this paper is based on three assumptions. First, the United States will need new technologies to meet its increasing energy demands by the end of the century. While the world energy demand is expected to double in a period of 20 to 30 years [1], a recent study by the U.S. Department of Commerce indicates that the nation's need for energy will grow $1.2 \%$ per person through the end of the century, and that the economy will grow by about $2.2 \%$ per year [2]. Second, this increasing demand for energy, deemed essential in order to maintain an acceptable level of economic activity, coupled with the demand for energy security in the United States that followed the oil crisis of 1973-74, will necessitate the exploration of all reasonably promising energy alternatives [3]. According to the National Energy Plan [4], these principal alternative energy sources available to the United States-coal, nuclear power, and solar power (direct and indirect)-will be used in the years ahead. Finally, the steadily rising cost of coal, the probable scarcity and increasing costs by the year 2000 of petroleum, natural gas, and U235 , and a growing concern over the detrimental environmental effects of these energy sources will make them increasingly less economic for large-scale electrical generation. Substitute sources include non-U-235 nuclear energy, geothermal energy, and various forms of solar energy, including ocean thermal energy conversion (OTEC).

OTEC, an unconventional energy source and a unique energy technology, is an attractive alternative for several reasons.

[l] $t$ can provide utilities with "baseload capability" on line 24 hours a day. It can economically generate power at a level of 250 megawatts and up, enough for a moderate-sized city. Using a renewable resource, the sun, its "fuel" is delivered directly to the site in usable form without charge. It is environmentally benign, emits no poisonous by-products (barring the remote contingency of a massive leak of the working fluid-probably ammonia), and it is necessarily situated unobtrusively offshore, away from population centers [5].

Despite these attractive features, however, established utilities have shown little interest in pursuing technological studies and hardware demonstrations related to OTEC. This apparent lack of serious interest stems mainly from the perception that OTEC is an expensive, unproven, and risky undertaking. A combination of factors is responsible for the prevailing skepticism: unproven economics (based on presently noncompetitive estimated costs of OTEC-generated energy), unverified social and environmental effects, and uncertainty as to the potential of energy from OTEC, as well as how OTEC fits into the national energy policy. The absence of an adequate legal and institutional framework further clouds the picture.

It seems that the uncertainty OTEC faces on technological and economic grounds will be dispelled by further studies and demonstration projects that are likely to be undertaken

*The author has greatly benefited from the studies cited in notes 9 and 70 infra (several of these prior studies were supported by DOE), as well as from my discussions with Jan Laitos, George Morgan, and Jon Veigel of the Solar Energy Research Institute. However, the author alone is responsible for the contents of the paper. 
by the Department of Energy (DOE) [6]. While the "engineering challenges to be bridged demand solutions of scale rather than of technical innovation" [7], it is estimated that "the OTEC power plant should have an economic advantage over fossil fuel plants and nuclear plants well before the year 2000" [8].

However, these economic and technological issues will not be discussed here, nor will the financial aspects be investigated in this study [9], which has as its primary focus those legal and institutional aspects that will ostensibly have a significant bearing upon the commercialization of OTEC. These issues are broadly classified as jurisdictional, regulatory, and environmental. They will be discussed here in the context not only of existing international law-both customary and treaty law-but also of the current developments in the law and the probable changes in it, particularly those resulting from ongoing negotiations of the Third United Nations Conference on the Law of the Sea (LOS III) [I0]. Several alternatives will be discussed and recommendations offered in each area in light of the United States' interests.

This discussion will be prefaced by a short assessment of the possible arrangements for the siting of OTEC plants, their functions, and their potential for the United States [11]. The two most likely configurations for OTEC plants will be: (1) an OTEC facility operating individually as a semipermanent fixture, or a number of plants moored in clusters of 9 to 10 plants around a central collection device and connected to shore by a transmission cable, supplying electrical power for general consumption to a land-based electricity grid; or (2) an open sea O'TEC facility, a plant ship, migrating and "grazing" on the surface, seeking the maximum thermal differential gradient and supplying power for an energy-intensive industry at sea. Such a facility could, for example, produce ammonia on-site to be used for the production of fertilizers and industrial chemicals, or aluminum, or engage in energy-intensive commodity processing such as manganese nodules. The energy produced then could be converted into other forms of energy, such as hydrogen, and the products produced on-site transported to shore by vessel. Such products could also be manufactured and processed in such places as Hawaii and Puerto Rico, which are close to some of the prospective sites of OTEC facilities.

Because of the thermal gradient needed to make OTEC operative, tropical regions within $10^{\circ}$ of the equator offer the most promising sites for OTEC facilities that fit into configuration (1) discussed above. These regions comprise about 20 million square miles, where the surface water is around $80^{\circ} \mathrm{F}$, and the cold water 3,000 feet below is around $40^{\circ} \mathrm{F}$. For the United States, these sites are limited to the Gulf Coast, Hawaii, Puerto Rico, and the Pacific territories. According to the studies of the Energy Research and Development Administration (ERDA), a thermal resource of at least 300,000 megawatts lies just off the west coast of Florida [12]. It is anticipated that the technological developments expected from DOE's current OTEC Research, Development, and Demonstration (RD\&D) Program would allow the exploitation of this resource. Other studies indicate that the off-grid applications mentioned in configuration (2) will have a market potential of an average of 30,000 to 40,000 megawatts during the years 2000 to 2025 [13].

Finally, it should be noted that as a "legal reconnaissance paper," this paper relies heavily on the prior work done in the field. It attempts to provide in summary fashion, an outline of the major challenges that the establishment of a legal and institutional framework (both in national and international settings) for OTEC development is likely to pose. Within this broader context, it examines in some detail the question of federalstate relationships regarding jurisdictional and regulatory issues in U.S. offshore waters; a crucial subject which thus far has not been given adequate attention by commentators. 


\section{SECTION 2.0}

\section{JURISDICTIONAL, REGULATORY, AND ENVIRONMENTAL ISSUES}

Regardless of the site of an OTEC facility or its system and configuration, ownership, operation, energy potential and use, the move toward OTEC commercialization will be facilitated if the prevalent uncertainties regarding the issues discussed in this section are removed and an adequate legal and institutional framework is established, offering guidelines to interested parties. The following discussion, designed to present a broad outline of such a framework, surveys the current state of the law, suggests likely changes, identifies existing ambiguities, gaps, and uncertainties, and makes recommendations to remove them.

\subsection{JURISDICTIONAL ISSUES}

In the United States offshore areas, questions of jurisdiction (that is, questions pertaining to the competence to prescribe and apply the governing law to peoples, events, and activities in these areas) arise in two contexts: national-international and federalstate. In the former, activities are governed by norms established by multilateral treaties, regional and bilateral arrangements, and customary law, supplemented by unilateral action; in the latter, by statutory law and judicial pronouncements.

\subsubsection{National-International Issues}

The unsettled state of the Law of the Sea is responsible for unresolved jurisdictional issues pertaining to the installations of OTEC devices in offshore areas. The law is still in an evolutionary state and LOS III, which adjourned its seventh session in New York on September 15, 1978, and will convene its next session in Geneva on March 19, 1979 [14], is attempting to formalize a comprehensive and generally acceptable convention dealing with all aspects of ocean space. While differences on some key issues, such as the mining of the deep seabed, still remain unresolved, the negotiations have shown a remarkable consensus on most issues likely to affect OTEC deployment and operation. Also, regional and bilateral arrangements and unilateral state practices and claims are instrumental in changing the traditional Law of the Sea. These evolving changes will be discussed in this section following a brief outline of the traditional law.

The basic issue pertinent to the present discussion is a coastal state's rights in adjacent waters and on the high seas. Under traditional international law, the inquiry has centered on the limit of territorial waters, and additionally, since the 1958 Geneva Conventions on the Law of the Sea [15], on the extent of contiguous zones and the outer limit of the continental shelf. Beyond these areas, the universally applicable concept has been freedom of the high seas.

\subsubsection{OTEC Devices Under Traditional International Law Regarding the Territorial Sea}

Historically, coastal nation states have enjoyed certain exclusive rights and privileges with respect to adjacent waters over a narrow belt of three marine miles along their coasts, measured from the low water mark, that constituted their territorial waters [16]. These rights are similar to those they exercise over their internal waters and land masses, and were subject only to innocent passage of foreign vessels through these waters [17]. During the last 50 years, however, the breadth of territorial waters has been 
marked by a lack of uniformity. While the international conferences in 1930 [18], 1958 [19], and 1960 [20], failed to reach agreement on the limits of the territorial sea, the 1958 conf erence did adopt a proposal which perhaps could be read to measure the breadth of the territorial seas restrictively rather than defining it in affirmative terms. Article 24(1) of the 1958 Convention on the Territorial Sea and the Contiguous Zone [21] provides a coastal state limited jurisdiction over the high seas contiguous to its territorial sea, by granting the control necessary to "(a) prevent infringement of its customs, fiscal, immigration or sanitary regulations within its territorial sea; (b) punish infringement of the above regulations within its territorial sea." This zone "may not extend beyond 12 miles from the baseline from which the breadth of the sea is measured" [22] .

Article 24 did not guarantee coastal states the same specified rights in the contiguous zones as they enjoy in their territorial waters [23]; however, it implied a limitation of the coastal state's right to exercise those essential rights beyond the 12-mile limit. The Convention thus precluded a coastal state from claiming territorial waters beyond 12 miles.

Thus, under traditional international law, an OTEC device deployed for research [24] or commercial purposes within the territorial limits would be within the exclusive competence of the coastal state, since the term "sovereignty" has been continuously used to describe a coastal state's rights in territorial waters [25].

\subsubsection{OTEC Devices Under the Emerging Law on the Territorial Sea}

Although the 1958 convention failed to set a definite limit on the breadth of the territorial waters, state practices were fast eroding the traditional 3-mile limit. A United Nations Secretariat study in 1968 revealed that fewer than one-third of the states reporting ( 30 of $y 2$ ) had opted for less than 6 miles, while nearly half ( 43 of 92 ) opted for 12 miles or more, and only a small number (9) were claiming more than 12 miles [26].

The current product of the LOS III negotiations is the Informal Composite Negotiating Text (ICNT), a massive document containing 303 articles and 7 annexes [27]. This text sets the breadth of the territorial sea at 12 miles [28], and that of contiguous zones for similarly specified purposes as were contained in the 1958 convention at 24 miles [29]. Within this adjacent maritime belt, a coastal state's sovereignty is recognized as extending to the air space over the territorial sea as well as to the seabed and subsoil [30], and is limited only by the right of innocent passage [31].

Although ICNT is to "serve purely as a procedural device and . . . only provide a basis for negotiation without affecting the right of any delegation to suggest revisions in the search for a consensus" [32], there is an almost universal consensus on the 12-mile limit for the territorial seas. Within this zone, the coastal state will have almost total control over the installation and operation of an OTEC facility, both for research and commercial use.

\subsubsection{OTEC Devices on the Exclusive Economic Zone and the Continental Shelf}

Exclusive Economic Zone [33]. Beyond the 12-mile territorial sea and the 24-mile contiguous zone, ICNT recognizes a special area known as the Exclusive Economic Zone (EEZ), that extends seaward to a distance of 200 nautical miles from the baseline from which the breadth of the territorial sea is measured [34]. This zone has a special relevance for OTEC siting, because ICNT grants the coastal state "sovereign rights for the purpose of exploring and exploiting, conserving and managing the natural resources, 
whether living or nonliving, of the seabed and subsoil and the superjacent waters, and with regard to other activities for the economic exploitation and exploration of the zone, such as the production of energy from the water, currents and winds" [35].

Additionally, the coastal state's jurisdiction extends within EEZ to "(1) the establishment and use of artificial islands, installations and structures; (2) marine scientific research; (3) the preservation of the marine environment" [36]. Other states enjoy some of the traditional freedoms of the high seas in EEZ-freedom "of navigation and overflight and of the laying of submarine cables and pipelines" [37], but not fishing, scientific research, or pollution control-that are presently under the exclusive jurisdiction of coastal states.

The establishment of EEZ is perhaps the most significant development in the Law of the Sea since President Truman's Proclamation on the Continental Shelf in 1945 [38], that claimed for the United States the natural resources of the seabed and the subsoil of its continental shelf lying beyond the traditional 3-mile limit. A variety of claims for exclusive jurisdiction by coastal states over the high seas area beyond their territorial seas followed the Truman proclamation. The most notable claims initially were by several Latin American countries to a 200-mile territorial sea [39], and more recently by Canada to a 100-mile pollution control zone [40].

Subsequently, when LOS III began its deliberations, two proposals formed the basis of what has finally emerged as EEZ: one, a 200-mile economic zone proposed by a majority of African states [41], and the other, an exclusive "Patrimonial Sea" with an outer limit of 200 miles and similar jurisdiction over the natural resources up to the edge of the continental margin, adopted at the 1972 Santo Domingo Conference by a group of Caribbean countries [42]. Although these zones were originally conceived as essentially resource-control zones, the coastal states' powers are greatly enhanced by the grant of "exclusive jurisdiction" to them regarding exploration and exploitation, pollution control, and scientific research.

Although ICNT does not specifically mention coastal states' jurisdiction over OTEC activities within EEZ, it would be a valid conclusion that coastal states will have exclusive competence over the deployment and regulation of OTEC installations within their EEZ for research purposes or commercial operations. Any reasonable interpretation of ICNT provisions will support this conclusion. To illustrate, Article 56(a) grants a coastal state "sovereign rights" within EEZ for "other activities for the economic exploitation and exploration of the zone, such as the production of energy from water, currents, and winds." "This would obviously include the energy produced by an OTEC operation. Article 60 explicitly provides for a coastal state's "exclusive right to construct and to authorize and regulate the construction, operation, and use of: (a) Artificial islands; (b) Installations and structures for the purposes provided for in Article 56 and other economic purposes; (c) Installations and structures which may interfere with the exercise of the rights of the coastal State in the zone." Article 247(2) provides that "[m] arine scientific research activities in the exclusive economic zone and on the continental shelf shall be conducted with the consent of the coastal State." Moreover, there is such an overwhelming consensus among the participants at LOS III on EEZ that even if the efforts to formalize a comprehensive treaty on the Law of the Sea were to fail, EEZ in the near future will be accorded legitimacy by state practices, transforming it into a rule of customary international law.

It appears that the coastal state's permission would be required to install an OTEC device on its EEZ either for research purposes or commercial operation. Until now, no nationstate has adopted specific legislation addressing this issue. However, once OTEC 
technology and economics are proven, such legislative measures prescribing conditions for access to EEZ and outlining the legal and institutional arrangements under which a foreign entity is permitted to operate an OTEC facility within that zone, will in all probability be adopted by countries wishing to attract a foreign owned/operated OTEC facility within its EEZ. Bilateral and regional arrangements regarding the deployment and operation of an OTEC device within a coastal state's EEZ would be another way of establishing conditions for the installation of OTEC devices within an EEZ.

Continental Shelf. Under the 1958 Geneva Convention on the Continental Shelf [43], "sovereign rights" of the coastal states in the continental shelf (defined as beginning at the seaward limit of the territorial sea and continuing to the 200-meter isobath) [44], are restricted to "exploring it and exploiting its natural resources" [45], leaving unaffected the "legal status of the superjacent waters as high seas, or that of the airspace above those waters" [46]. A coastal state's consent is imperative for any scientific research concerning the continental shelf and being conducted there [47].

Thus, although theoretically an OTEC device of another nation could be moored on a coastal state's continental shelf, while the device itself is located on the high seas, provided it did not interfere with the coastal state's exclusive right to exploit natural resources in that area [48]; the prospects that this would happen are unlikely without the consent of the coastal state. A coastal state's special rights in adjacent waters with regard to scientific research and pollution control are widely accepted, and with the emergence of EEZ, such a possibility without the coastal state's consent could be ruled out.

ICNT modifies the definition of the continental shelf by providing that it extends to the outer edge of the continental margin or to a distance of 200 miles when the outer edge of the continental margin does not extend that far [49]. While other ICNT provisions [50] do not substantially change the prior law, articles pertinent to OTEC siting should be noted.

Article 80 on "Artificial Islands, Installations, and Structures on the Continental Shelf," provides that Article 60, which grants the exclusive right to the coastal state to construct, authorize, and regulate construction, operation, and use of such artificial islands, installations, and structures, applies mutatis mutandis. Similarly, Article 247 adopts the consent regime for scientific research on the continental shelf, al though some of the obstacles for conducting research in the waters above the continental shelf have been ameliorated [51].

The conclusion is inescapable that a coastal state will have exclusive competence over the installation of any OTEC device located over its continental shelf for research or commercial purpúses.

\subsubsection{OTEC Devices on the High Seas}

Traditional Law. Under the freedom of the seas concept, every nation has unrestricted access to the high seas, but none is permitted any long-term appropriation of any part of the high seas for its exclusive use. Queen Elizabeth I of Ingland is generally credited with first enunciating the freedom of the seas in her response to Spanish complaints against the expeditions of the English navigator, Drake: "the use of the sea and air is common to all; neither can any title to the ocean belong to any people and private man forasmuch as neither nature nor regard of public use permitteth any possession thereof" [52]. 
This principle was recently reaffirmed by the U.S. Supreme Court:

[T] he high seas, as distinguished from inland waters, are generally conceded by modern nations to be subject to the exclusive sovereignty of no single nation .... The extent to which a nation can extend its power into the sea for any purpose is subject to the consent of other nations, and assertion of jurisdiction to different distances may be recognized for different purposes [53].

The practical reasons for the universal acceptance of this principle. lie in (1) the increasing use of the ocean as an international highway for commerce during the postIndustrial Revolution era, that coincided with the period of Western colonialism in the 18 th and 19th centuries, and (2) the lack of effective occupation of large areas of ocean claimed by major powers [54].

In 1958, the Geneva Convention on the High Seas codified the essence of the freedom of the seas by providing both for coastal and noncoastal states:

- freedom of navigation;

- freedom of fishing;

- freedom to lay submarine cables and pipelines; and

- $\quad$ freedom to fly over the high seas.

These freedoms and others that are recognized by the general principles of international law shall be exercised by all states with reasonable regard to the interests of other states in their exercise of the freedom of the high seas [55].

Obviously, many of these freedoms-commercial navigation, military uses, fishing, laying of submarine cables and pipelines-give rise to conflicting uses of the high seas. For the management of these conflicting uses, the standard is that of reasonableness with regard to the interests of other users, that is, not unreasonably interfering with their uses. The deployment of an OTEC device for research or commercial purposes could be justified under this "reasonable use" concept. The recent U.S. legislation authorizing the construction of deep water ports beyond the limits of its territorial sea [56], which it justified on this reasonable use theory [57], offers an appropriate precedent. Since states traditionally have the primary responsiblity for regulating the activities of vessels flying their flags on the high seas, applying that analogy to OTEC devices, any OTEC installation owned or authorized by a state on the high seas would be under its authority and control. Similarly, under the laws of nationality, nationals are always and everywhere subject to the laws of their nation state [58] and their activities on an OTEC device on the high seas would be governed by the laws of the state of their nationality.

LOS III and the Deep Seabed. Current negotiations in LOS III are still stymied on the nature and scope of the proposed regime for deep seabed mining [59]. Nevertheless, pertinent ICNT provisons which have a bearing on the deployment and operation of an OTEC facility will be considered here. This discussion will be prefaced by noting the United Nations General Assembly Resolution 2749 of December 17, 1970 [60], which declared, among other things, that: 
- The seabed and ocean floor, and the subsoil thereof, beyond the limits of national jurisdiction (hereinafter referred to as the Area), as well as the resources of the Area, are the common heritage of mankind.

- The Area shall not be subject to appropriation by any means by states or persons, natural or juridical, and no state shall claim or exercise sovereignty or sovereign rights over any part thereof.

ICNT attempts to give concrete shape to the "common heritage" concept. It declares the area constituting "the seabed and ocean floor and subsoil thereof beyond the limits of national jurisdiction" [61] (Area), and its resources to be "the common heritage of mankind" [62], and envisages the establishment of an International Seabed Authority (ISA) to organize and control activities in the Area. No state is to claim or exercise sovereignty there and no exclusive appropriation is permissible [63]. The legal status of the waters superjacent to the Area or that of the airspace above those waters are left unaffected [64]. While activities in the Area are defined as "all activities of exploration for, and exploitation of, the resources of the Area" [65], in subsequent provisions [66], activities are construed broadly as covering, among other subjects, those of marine scientific research, transfer of technology, and protection of the marine environment and human life. However, again in Article 150, activities are construed narrowly, referring only to exploration and exploitation of resources. Thus, there is considerable ambiguity regarding ISA's control in the Area.

Resources are defined as "mineral resources in situ" [67], which are subject to ISA's licensing and regulation [68]. Minerals include "water, steam, hot water" [69]. While it can be argued that ISA's jurisdiction extends to "fresh water aquifers and similar subsurface water sources, not the cold water lying near the seabed that might be used by an OTEC device" [70], a broad interpretation by ISA of these provisions is possible, under which OTEC deployment for scientific research or commercial purposes would be covered [71]. Also, despite the current provision under which ISA has no jurisdiction over the superjacent waters of the high seas [72], it is possible that its jurisdiction in the near future will extend to activities in the water column and on the surface [73], thereby affecting OTEC operations. Such an outcome would be consistent with the growing demands of the developing states for a strong ISA that could give meaning to "the common heritage" concept. Similarly, the mooring of an OTEC device on the high seas, that would require corings and other physical investigations of the ocean floor and the seabed, could be perceived as an economic use of the Area and, therefore, subject to ISA's jurisdiction. Additionally, ISA could asume jurisdiction, should such mooring pose any actual or potential interference to seabed mining activities that are to be regulated by ISA. Of course, ISA could assert jurisdiction over marine scientific research in the Area that is to be carried out "exclusively for peaceful purposes and for the benefit of mankind as a whole" [74].

Consequently, it appears that under the envisaged seabed regime, OTEC activities on the high seas could be subject to the jurisdiction of the proposed ISA. Perhaps two exceptions to ISA jurisdiction are possible: (1) a coastal state extends its competence to an OTEC facility that lies beyond its EEZ, but that poses an actual or potential threat to its living and nonliving resources by adversely affecting the marine environment, or (2) if there is no accord at LOS III on a deep seabed regime and the existing law applies under which the deployment of an OTEC facility on the high seas could be justified under the "reasonable use" concept. 


\subsubsection{Recommendations}

The major objectives of the United States that determine its policy on nationalinternational jur isdictional issues include freedom of navigation and the establishment of an equitable regime for deep seabed mining. Since energy sources in the oceans including OTEC are of considerable significance to the United States, U.S. negotiators at LOS III should pay close attention to the implications of the emerging treaty on OTEC siting and deployment in adjacent coastal waters, as well as on the high seas. The primary questions for consideration would be:

- Is it in the United States' interest to seek freedom of OTEC siting and deployment in the emerging 12-mile territorial seas and EEZ?

- What kind of regime regarding OTEC activities on the high/seas should the United States seek?

- If efforts to finalize a comprehensive treaty on the Law of the Sea fail, what kinds of claims would be in the United States interest to assert? A brief discussion of these questions follows.

Apparently, ICNT provisions regarding the extension of coastal states' boundaries to a 12-mile territorial zone and a 200-mile EEZ are acceptable to the United States. Consequently, there are two policy options open to the United States regarding these zones. One is to accept the coastal states' exclusive competence in the region, that will exclude any U.S. OTEC siting in foreign waters within these zones without the coastal state's consent; the other is to seek freedom of OTEC activities within these zones.

There does not seem to be any chance of reversing the widely accepted policy of exclusive coastal state competence in the territorial waters even if the United States were to vigorously seek an exception for OTEC activities. Similarly, despite some ambiguities regarding EEZ [75], no exceptions in favor of OTEC activities in this zone are likely to be accepted by a majority of nations at the current LOS III negotiations. The United States could, perhaps, still seek such an exception if it were found to be in its interest and could make appropriate reservations to the finalized treaty. However, in light of the recent developments regarding a coastal state's assertion of its competence in coastal waters, especially pertaining to marine pollution and natural resources, it is unlikely that such a U.S. assertion would be recognized by other states. Thus, it is recommended that the United States accept the 200-mile coastal state competence regarding OTEC siting and deployment. This course of action would appear to be beneficial to the United States as well, since it has major OTEC sources lying off the west coast of Florida, Hawaii, and Puerto Rico. The recent U.S. extension of its fishery zone [76], and the establishment of zones to enforce navigation safety rules [77] and to control pollution [78], indicate that there would be a strong demand in the U.S. Congress to assert such a control. It is recommended that as a first desirable step, Congress enact legislation creating a Coastal Energy Conservation and Management Zone extending to a 200-mile limit. Under this proposed legislation, the United States will claim jurisdiction for the specific purpose suggested by the title: energy conservation and management. The proposed legislation will be an interim measure seeking limited jurisdiction patterned after the Deepwater Port Act (DPA) [79] model, to be superseded by the legislation required to implement the EEZ provisions of the Law of the Sea Treaty when it is concluded.

'The high seas, on the other hand, present a different set of challenges. Since the United States will presumably have the necessary technology and wherewithal to engage in 
OTEC activities on the high seas for research as well as for commercial purposes, perhaps the United States could seek to modify ICNT at the next session to specifically exclude OTEC acitvities from the competence of ISA. If the current discussion in LOS III negotiations on the deep seabed regime is any indication of what might be the regime pertaining to OTEC activities, such prospects do not look promising. The developing countries seek a strong ISA and are not willing to accept OTEC activities being excluded from its jurisdiction, for they could argue that OTEC uses a resource covered under the concept "common heritage of mankind." If a treaty does not emerge, the United States could rely upon a reasonable use theory to engage in OTEC activities on the high scas.

The DPA offers a model of legislation for this purpose. The U.S. Congress specifically declared therein that nothing in the Act "shall be construed to affect the legal status of the high seas, the superjacent airspace, or the seabed and subsoil, including the Continental Shelf" [80]. The U.S. President is authorized and requested under the Act to enter into negotiations with the neighboring governments of Canada and Mexico to determine "the desirability of undertaking joint studies and investigations designed to ... eliminate any legal and regulatory uncertainty" [81]. As a condition to the issuance of a license for the ownership, construction, and operation of a deepwater port, the Secretary of Transportation determines that "the deepwater port will not unreasonbly interfere with international navigation or other reasonable uses of the high seas, as defined by treaty, convention, or customary international law" [82]. Also, the designation of safety zones is "[s] ubject to recognized principles of international law" [83], and the Secretary is required to prescribe various regulations, relating to activities involved in site evaluation and preconstruction testing at potential deepwater locations that may interfere with authorized uses of the outer continental shelf [84]. Additionally, the environmental review criteria that are to be used to evaluate $\dot{a}$ proposed deepwater port include "the effect on alternate uses of the ocerns and navigable waters, such us scientific study, fishing, and exploitation of other living and nonliving resources" [85]. The duration of a license is limited to 20 years [86].

\subsubsection{Federal-State Issues Related to OTEC Devices}

In U.S. coastal waters, unresolved questions still remain regurding the demarcation of authority between the Federal Government and the adjacent coastal states. Further uncertainty is likely when the United States decides to expand.its territorial seas to a 12mile limit and subsequently to claim its 200-mile EEZ, the two probable prospects with or without a comprehensive Law of the Sea treaty. The primary question is, what would be the states' rights in the newly acquired territory?

Since federal-state jurisdictional issues may affect the research and demonstration phase of OTEC, as well as its advanced development phase for commercial purposes, this section will briefly describe, in an historical context, the current law on federal-state jur isdiction in coastal areas. This will be followed by a discussion of the probable impacts of the extension of U.S. boundaries in the oceans on federal-state authority in the extended zones and on OTEC research and development.

\subsubsection{Current Law}

The 1945 Truman Proclamation [88], that extended U.S. jurisdiction to its continental shelf, left unresolved the question of federal versus state authority over the shelf [89]. However, in a number of cases in the following five years [90], the Supreme Court held that the Federal Government had paramount rights in and full dominion over the resources in the territorial sea. Since several states had already granted leases for 
offshore oil production in the 3-mile limit, these Supreme Court decisions generated strong political pressure [91], to which the U.S. Congress responded in May 1963, by enacting the Submerged Lands Act [92]. This Act gave the states title and ownership of land and resources lying beneath the water extending seaward to its 3-mile limit [93], subject, however, to the continued U.S. authority and rights over such lands and waters "for the purposes of navigation or flood control or the production of power" [94]. Under the Act, the United States expressly retained "all its navigational servitude and rights in and powers of regulation and control of said lands and navigable waters for the constitutional purposes of commerce, navigation, national defense, and international affairs" [95] .

Six years after the enactment of the statute, a federal district court specifically recognized the paramount power of the United States to control such waters for the purposes of navigation in interstate and foreign commerce [96]. More recently, federal courts have confirmed that under the Act, Congress did not surrender to the states its constitutional power to regulate foreign commerce [97]. Federal courts also have recognized the primacy of ongoing federal interests in the seabed [98], over the superjacent waters and their resources [99], and surface activity in the 3-mile territorial sea $[100]$.

In August 1953, just three months af ter the enactment of the Submerged Lands Act, the Outer Continental Shelf Lands Act [101] implemented the 1945 Truman Proclamation by declaring the policy of the United States: "that the subsoil and seabed of the outer Continental Shelf appertain to the United States and are subject to its jurisdiction, control, and powér of disposition" [102]. While the Act recognizes "the character as high seas of the waters above the outer Continental Shelf," thus leaving unaffected the right to navigation and fishing in such waters [103], it specifically provides:

The Constitution and laws and civil and political jurisdiction of the United States are extended to the subsoil and seabed of the outer Continental Shelf and to all artificial islands and fixed structures which may be erected thereon for the purposc of exploring $f \mathrm{r}$, developing, removing, and transporting resources therefrom, to the same extent as if the outer Continental shelf were an area of exclusive federal jurisdiction located within a state: Provided, however, That mineral leases on the outer Continental Shelf shall be mainluined or issued only under the provisions of this subchapter. [104]

To the extent that they are applicable and not inconsistent with ... Federal laws and regulations, ... the civil and criminal laws of each adjacent State as of August 7, 1953, are declared to be the law of the United States for that portion of the subsoil and seabed of the outer Continental Shelf, and artificial islands and fixed structures erected thereon. [105]

Under the Act, the Coast Guard is authorized to make and enforce regulations "with respect to lights and other warning devices, safety equipment, and other matters relating to the promotion of safety of life and property on the islands and structures" erected on the Outer Continental Shelf (OCS) [106]. While the Secretary of the Interior is authorized to administer and regulate the leasing of the OCS [107], the Secretary of the Army is authorized to prevent obstruction to navigation which may be caused by artificial islands and fixed structures located on OCS [108]. The Act provides for the application of the civil and criminal law of coastal states existing on the effective date of the Act to the activities on the subsoil and seabed of OCS, including artificial islands and fixed structures erected there [109]. In 1975 Congress amended the Act to apply current state laws [110]. 
These statutes did not resolve the federal-state controversy regarding the proper authority and control for the exploration and exploitation of OCS. The states continued to claim a stronger voice in the decision-making process because of the direct impact of OCS development on the states. In response to a U.S. complaint against 13 Atlantic coastal states that they were interfering with the exclusive U.S. rights to explore and exploit the natural resources of OCS, in 1975 the Supreme Court in United States v. Maine [111], reaffirmed its earlier decisions that the Federal Government had "paramount rights in the marginal seas" [112] as attributes of its external sovereign powers.

More recently, however, the recognition of the coastal states' interest in activities over OCS has been evident in several new developments, including (1) the formation of regional OCS advisory boards, made up of state representatives [113]; (2) the devising of a new system under which the Department of the Interior will share with the states information regarding lease tracts [114]; and (3) the 1978 Amendmonts to the Outer Continental Shelf Lands Act [115] under which states will be given a significant role in decision making pertaining to leasing [116].

Several other federal statutes permit federal-state participation in planning offshore activities [117], including the DPA [118] and the Coastal Zone Management Act (CZMA) [119].

Under DPA, interested states are given an advisory role both in the formulation of regulations to carry out the purposes of the Act [120] and in the issuance of deepwater port licenses [121]. Deepwater ports within the 3-mile territorial waters of the United States are excluded from the federal licensing scheme [122], leaving thereby deep-draft harbors under the authority of the states and the Corps of Engineers [123]. A noteworthy feature of the federal-state sharing of authority in DPA is that the Secretary of Transportation is not to issue a license to own, construct, or operate a deepwater port facility without the approval of the governor of each adjacent coastal state [124]. This stipulation effectively grants the governor veto power over a deepwater port application [125]. A state is to be so designated by the Seretary when it would be direelly connected by pipeline or would be located within 15 miles of a proposed deepwater port [126]. Also, the Secretary could designate a state as an adjacent coastal state if he determines, pursuant to a request by the state and the recommendation of the administrator of the National Oceanic and Atmospheric Administration (NOAA), that "there is a risk of damage to the coastal environment of such State equal to or greater than the risk posed to a State directly connected by pipeline to the proposed deepwater port" [127].

Adjacent coastal states are also given preferential rights to deepwater port licenses under DPA [128]. As an original licensee, a state may transfer its license provided the transferee complies with the requirements of the Act [120]. Also, tlic luw of the nearest adjucent coastal state-the state "whose seaward boundaries, if extended beyond three miles, would encompass the site of the deepwater port" [130]-is made applicable under the Act to licensed deepwater ports. Another notable provision is the authorization of an adjacent coastal state to "fix reasonable fees for the use of a deepwater port facility" [131]. Such fees are subject to the approval of the Secretary of Transportation and are not to exceed economic, environmental, and administrative costs of such state [132].

CZMA is designed to protect coastal resources by encouraging states to manage the coastal areas [133]. Federal-state partnership is envisaged, for the Act requires that federally conducted or supported activity within or directly affecting the coastal zone 
must be carried out in a manner "which is, to the maximum extent practicable, consistent with approved state management programs" [134]. This "consistency" requirement is made applicable specifically to the OCS development activity [135]. A set of federal regulations defines terms and establishes guidelines for the approval of coastal zone management programs [136].

CZMA Amendments of 1976 created a coastal energy impact program [137] that authorizes $\$ 800$ million for the creation of a coastal energy impact fund for loan guarantees and grants to states having an approved coastal zone management program or making satisfactory progress in developing such a program [138]. Loans and loan guarantees also are authorized to aid coastal states in financing new or improved public facilities and services needed to handle new or expanded coastal energy activities. Also, grants are authorized from the fund to help the states plan for the consequences of increased coastal energy activities and to aid the states in preventing or mitigating unavoidable losses of valuable environmental and recreational resources [139].

\subsubsection{Federal-State Issues in Light of LOS III}

When the United States extends its boundaries to a 12-mile territorial sea and a 200-mile EEZ, three questions become pertinent: (1) Would the state zone be extended from 3 to 12 miles? (2) If such a state expansion were to take place, would the Federal Government preempt the states in energy matters, including OTEC? and (3) Who would be the licensing authority and what would be the licensing requirements? Since the coastal state is given police power over such islands and structures, the question arises as to which laws would be made applicable to them. In regard to the last question, the model provided by the Outer Continental Shelf Lands Act [140], and DPA [141], applies the law of the adjacent coastal state. This would seem to be the desirable approach to adopt. Thus, the law of the state where the transmission cables go ashore will apply to the extent that it is not inconsistent with federal law. Other possiblities include the general maritime law or the law of the state in which the OTEC firm is incorporated.

\subsubsection{Recommendations}

The primary concern regarding federal-state jurisdictional issues in adjacent coastal waters relates to an efficient management of the 200-mile marine zone. There are arguments in favor of either leaving the coastal states' boundaries fixed at the 3-mile limit or extending them to 12 miles. A commentator has aptly summarized the pros and cons:

On the federal side arguments could be advanced that the interest of inland States and of all citizens, the history of the sea as of national strategic importance, as well as greater naval and administrative capacity, weigh in favor of federal control.

On behalf of the States, it could be maintained that leaner, more responsive agencies, closer familiarity with daily, mundane marine-related affairs, and a diversity of local concerns render the States the preferred government to exercise authority over an expanded territorial sea. [142]

Irrespective of who owns the extended stretch of 9 miles, it is imperative that there be appropriate appreciation and recognition of mutual interests by the Federal Government and the coastal states in the 12-mile zone. Beyond this zone, within a 200-mile EEZ (assuming that with or without a new LOS convention the United States asserts its 
jurisdiction in this area), the Federal Government will have the primary authority to regulate OTEC activities. However, in specific situations, where a coastal state has a substantial interest, an accommodation of federal/state interests will be desirableindeed necessary. For instance, a state has such a special interest when an OTEC operation is connected to the shore by a transmission cable and/or a state utility is involved because an OTEC taps into a land-based electricity grid. While these issues will be briefly examined in the next section on regulatory issues, earlier developments regarding OCS, DPA, and CZMA provide useful precedents for an accommodation of the federal/state interests. However, it seems that what is sorely needed is a cohesive U.S. policy for a 200-mile maritime zone and an efficient and strong institutional structure to implement it. At present, several departments in the Federal Government are involved in both the formation and implementation of national policies in adjacent coastal waters [143]. Instead of a pi ecemeal legislative effort as a U.S. response to the demands posed by the extension of its maritime boundaries, an imaginative federal oceans policy should be fashioned which will facilitate an equitable resolution of federal-state issues.

During the last decade, a number of studies and reports on U.S. marine policy, including the 1969 report of the Commission on Marine Science and Resources (Stratton Commission), and reports by the National Advisory Committee on Oceans and Atmosphere (NACOA), have recommended the creation of a strong, independent, policysetting body that could coordinate effectively national ocean policies and implementing activities [144]. The argument for the formation of a single policy-formulating authority is that it can balance the various national interests that are of ten competing-national security, national economy, international trade, and the global ecosystem. The argument against such centralization is that a specialized oceans agency would detract from important programs based on functional activities, such as OCS gas and oil exploration, which are at present handled by the Department of the Interior, and "should remain in Interior because of the land development expertise of the Bureau of Land Management and the U.S. Geological Survey" [145].

In October 1977, Senate Bill S.2224 [146] was introduced "to establish a national ocean policy and to set forth the missions of the National Oceanic and Atmospheric Administration (NOAA)." Asserting that U.S. ocean policy had long suffered from disparate processes and duplication of effort, the bill seeks to strengthen NOAA as the leading, civilian, ocean policy agency responsible for coordinating national ocean policy. The current situation is aptly summarized in a recent report by an observer:

The important question is whether the ocean community should settle for the problems engendered by the largely uncoordinated program activities in the marine environment, or demand federal action to improve control of governmental policies. No executive agency oversees all ocean programs. No congressional committee oversees all of the great number of program interests expressed through all the competing uses of the marine environment. There is no major policy perspective against which specific development options can be judged for cohesiveness. There is no responsible body to assist the President in the formulation of immediate goals based on long-term national interest. There exists no eriterion by which international or domestic concerns can be evaluated. The ocean environment encompasses such a vast array of important interests and considerations that muddling through by reacting to emergent needs is not in the best interest of the nation. [147] 
Proposals for the creation of a strengthened policy-setting body include the formation of a Cabinet-level Marine Affairs Council [148], a public corporation such as COMSAT, or a public body such as the Tennessee Valley Authority [149].

Based on a thorough appraisal and evaluation of current U.S. offshore policies, especially of federal-state authority and control in a myriad of activities occurring in this area, it is imperative that the administration of the government's oceans programs be centralized in a strong, effective, and independent body, and that federal-state jurisdictional and regulatory issues be resolved equitably. The next section will examine some of these issues, especially the ones relevant in the context of OTEC siting and development.

\subsection{REGULATORY ISSUES}

Regulatory issues will be considered in this section in two contexts, international and federal-state. This examination will be prefaced by a brief investigation of the legal status of OTEC devices.

\subsubsection{Legal Status of OTEC Devices [150]}

It is important to determine the legal status of OTEC devices because many rights and obligations of such entities and those owning, operating, and manning them will of ten flow from such a determination. Additionally, the conferring of legal status on OTEC devices, whether fixed to the ocean floor or movable either for station keeping or for grazing on the high seas, will legitimize their presence as well as their operation. The issue is two-fold: (1) Who would authorize their presence and operation by licensing them? (the analogy is that of a flag state authorizing the use of its flag on a vessel), and (2) Since traditionally a regulatory mechanism exists to regulate activities of structures designed as vessels on the oceans, would OTEC devices be considered vessels or quasivessels, at least for some purposes? The question of licensing will be discussed in the next section examining international and federal-state regulatory mechanisms.

Whether an OTEC device is considered a vessel will not dispose of the complex legal issues raised by OTEC presence as a new user of the sea. However, because of the status of commercial navigation as an ocean use of long standing, there are existing international guidelines, standards, and regulations applicable to vessels. It is useful to inquire whether the existing standards and regulations-those of safety, design and construction, collision and navigation, communication, and labor-will apply to OTEC devices and whether these regulations need to be modified in order to meet OTEC needs. Otherwise, new arrangements will have to be devised. In the national context, the status of OTEC devices as vessels could confer upon them substantial economic benefits, in view of the fact that the U.S. shipping industry is subsidized by the U.S. government by means of providing mortgage guarantees, construction and operation subsidies, and tax advantages [151].

It appears that only during the last decade have international agreements regulating activities on the sea broadened their reach to cover OTEC-type structures. The 1969 Convention on Intervention on the High Seas, dealing with oil pollution casualties set the stage by defining a ship as: "(a) any sea-going vessel of any type whatsoever and (b) any floating craft, with the exception of an installation or device engaged in the exploration of resources of the scabed and the ocean floor and the subsoil thereof" [152]. The Convention added a distinct category of "floating craft" to that of "vessel," the term 
traditionally used in such conventions. The 1972 Convention on the Prevention of Marine Pollution by Dumping of Wastes and Other Matter [153] defined vessels to include "floating craft, whether self-propelled or not" [154]. The Convention called upon each contracting party to apply means required to implement the present convention to "all vessels .... and fixed or floating platforms under its jurisdiction believed to be engaged in dumping" [155].

The 1973 Convention for the Prevention of Pollution from Ships [156] defines ship to mean "a vessel of any type whatsoever operating in the marine environment and includes hydrofoil boats, air-cushion vehicles, submersibles, floating craft, and fixed or floating platf orms" [157]. In addition to ships entitled to fly the flag of the Party, the Convention applies to "ships not entitled to fly the flag of a Party but which operate under the authority of a Party" [158]. Similarly, the 1976 Convention on the International Maritime Satellite Organization [159] defines a ship broadly as "a vessel of any type operating in the marine environment" including "inter alia hydrofoil boats, air-cushion vehirles, submersibles, floating craft, and platforms not permanently moored" [160]. It appears that the terms being used now such as "floating craft" and "floating platforms" wnuld include OTEC-type structures in the ocean environment. However, there are many conventions adopted under the auspices of the International Maritime Consultative Organization (IMCO), which do not cover OTEC-type facilities [161]. Which of these conventions should be made applicable to OTEC will depend upon the purpose of the convention and the probable benefit of its application to OTEC activities-both to the research and demonstration and development phases-so that its commercialization is facilitated and expedited.

ICNT provisions on pollution, on the other hand, would cover OTEC devices. Dumping is defined to include wastes or other matter from "vessels, aircraft, platforms or other man-made structures at sea" [162]. The terms used are "installations and devices," and "vessels, installations, structures and other devices," flying the flag of the mining states or of their registry [164]. Therefore, regardless of the status of OTEC devices, they would be regulated under ICNT.

\subsubsection{International Regulatory Mechanisms and OTEC [165]}

\subsubsection{Current Law}

It should come as no surprise that no regulatory mechanism exists for specific application to OTEC, for as a new technology it has yet to make its debut as a user of ocean space. of course, the primary purpose of providing a regulatory framework is to reduce uncertainty and risks attendant on pursuing OTEC activities. This is an important consideration not only for prospective investors, but also for eventual commercialization of OTEC.

It seems likely that in the initial stages of OTEC development for research and demonstration purposes and subsequently for commercial operation, broader guidelines and standards with built-in flexibility, rather than narrow, precise norms will be established. Developments in another relatively new area, transnational pollution [166], show that the important tasks of setting and harmonizing standurds and estalishing appropriate machinery for implementation usually occur first in regional settings [167] and appear later in a global setting where such need and feasibility have been clearly demonstrated. Because of unique regional situations, it is unrealistic to expect or even pursue universality and uniformity. The Regional Seas Program of the United Nations Environmental Program (UNEP) [168], which has developed in the last four years and is 
still developing action plans for seven regions-Mediterranean, Gulf of Arabia, Red Sea, Gulf of Guinea, Caribbean and adjacent regions, East Asian Seas, and South Pacificillustrates regional efforts on environmental management.

Several existing arrangements regulating other activities in ocean space could be construed to cover OTEC-type structures and activities on them, or with modifications, could be made applicable to OTEC. For illustrative purposes, a few examples of such arrangem ents relevant to OTEC follow.

The results of the last major effort to provide a framework for activities in ocean space, the 1958 Geneva Conventions, do provide some basis for regulating OTEC. For example, the freedoms enumerated in the High Seas Convention-navigation, fishing, laying of submarine cables and pipclines, and overflights [169]-are not exhaustive and it could be argued that OTEC activities do constitute a "reasonable use" of the high seas and fall within the scope of the freedoms granted under the Convention [171]. Other pertinent provisions of the Convention include those authorizing states to lay submarine cables, pipelines and communications lines [172], and those related to the states' regulation of the ocean pollution caused by their activities [173] .

The 1958 Convention on the Continental Shelf [174] contains prohibitions against (1) obstruction of the laying and maintenance of submarine cables and pipelines on the continental shelf [175], (2) the rights of coastal states affecting the legal status of the superjacent waters of the high seas [176], and (3) "any unjustifiable interference with navigation, fishing, or the conservation of the living resources of the sea" [177]. It also provides for the protection of "fundamental oceanographic or other scientific research carried out with the intention of open publication" [178].

As noted earlier, however, notwithstanding the provisions of the Convention on the Continental Shelf, the recent developments regarding extensive coastal states' claims in their offshore areas, especially the developments regarding EEZ, make it highly unlikely that OTEC activities could be conducted on another state's continental shelf without its cunsent [179].

The question of who would authorize operation of OTEC devices on the high seas is at present unsettled. Would the current state practice on vessels, the flag state approach (which ruises a further issue of the flags of convenience) [180], be made applicable; or, would the OTEC issue become as controversial as is the deep seabed mining issue at present [181]? It is premature to suggest the precise nature of the conditions and arrangements for OTEC activities on the high seas, for the current debate on the seabed mining issue and the conclusions which are finally reached at LOS III [182] will substantially affect the OTEC licensing and operations.

As noted earlier, most existing standards and regulations affecting activities in ocean space apply primarily to vessels, a term recently broadened to include OTEC-type structures [183]. Institutional arrangements, both in setting standards and providing mechanisms for compliance, are in various stages of development. One commentator describes the current state of affairs:

These arrangements cover areas such as safety, navigational aids, collision avoidance, design and construction regulation, inspection, certification, port entry, liability, communications, and labor and crew qualification. Most of these arrangements arise in national rather than internutional contexts, in most cases because international standards have not been agreed upon, or 


\begin{abstract}
because nations have not been willing to subject themselves to international authority. Some of these arrangements have been developed into conventions, which are binding on parties; others are still undergoing analysis by such forums as IMCO's Legal Committee in order to match institutional arrangements to the realities of ocean use ..... International forums have just begun to regulate moored platforms and other relatively novel marine technology. If OTEC devices are considered vessels, which is likely, at least for grazing type OTECs, then the various institutional arrangements currently providing norms and rules of vessel operation may apply or be amended to apply to OTEC development. [184]
\end{abstract}

Regulations applicable to marine pollution that might have a bearing on OTEC activities will be discussed in the next section dealing with environmental problems [185].

\title{
2.2.2.2 Recommendations
}

It is desirable to devise a regulatory scheme which assists DTEC oommorcialization by providing certainty to prospective investors. What must be carefully avoided is overregulation or an inflexible and cumbersome regulatory mechanism that can be stifling, especially for a new technology.

It is not to be expected that a new international regulatory mechanism will be established in the near future under a convention that deals specifically with OTEC operations. Experience shows that it was only in the aftermath of the Torrey Canyon disaster [186] that the current major conventions on marine pollution from ships were negotiated-the 1969 conventions on civil liability [187] and intervention on the high seas [1 88], and the 1973 convention on prevention of pollution from ships [189]. However, several existing mechanisms could be applied to OTEC activities. To illustrate, several IMCO cunventions currently applicable to vessels might be modified and made applicable to OTEC devices. Similarly, a functional approach is possible, authorizing specialized U.N. agencies to bring OTEC devices and operations under their regulatory framework: the International Energy Agenry, berause of OTEC's involvement with enelgy produc llon; the World Meteorological Organization (WMO), due to OTEC's research activities; the Food and Agricultural Organization (FAO), if OTEC-generated energy is used for producing fertilizers or in aquaculture; and the United Nations Environmental Program, owing to the potential environmental effects of OTEC operations. Of course, ISA could assume jurisdiction because of its umbrella function over the proposed deep seabed regime [190]. This is possible, especially in view of the "common heritage" concept [191], the likely OTEC conflict with deep seabed mining activities [192], or the possible environmentally adverse effects of OTEC operations [193].

It is recommended that, in addition to the prescription of unilateral U.S. regulations dealing with issues related to licensing and registration, safety, conflicting sea uses, communications, import and export, foreign labor, insurance, liability and compensation schemes, etc., attention be given now to the devising of imaginative bilateral and regional arrangements to apply to situations such as the following:

- The resolution of apparently competing interests of a coastal state and the licensing/registry state, where a foreign registered/licensed OTEC device is operating adjacent to a coastal state EEZ. The coastal state's interest in preventing harmful effects within its EEZ must be acknowledged and accommodated. 
- The use of bilateral or regional schemes under which a combination of a state or states and private enterprises pool their resources, technology, and knowhow to enter into arrangements for research and/or commercial purposes, such as, joint ventures to construct, operate, and own OTEC devices in a specific geographic area. The question of such operations on the high seas will, of course, have to be addressed separately, perhaps requiring some sort of global arrangement. The growing experience in working with satellite communication systems might off er useful guidelines. [194]

- The need for bilateral or regional consultative mechanisms which will address specific issues regarding the management of conflicting claims of ocean uses caused by OTEC presence. Fisheries arrangements [195] and existing agreements between neighbors on international waterways [196] offer useful precedents.

- The need for dispute settlement mechanisms.

On the global level, regulations regarding OTEC siting on the high seas might become necessary because of the possible conflicts between competing claimants to ocean uses or between competing claimants to attractive OTEC sites (a contingency not likely to occur in the near future). Thus, mechanisms might have to be devised to set standards and regulations concerning the licensing, operation, and allocation of OTEC sites for settlement of disputes, and to insure the efficient and optimal use of the oceans for OTEC development. In the long run, it might be desirable to establish an International Energy Resources Conservation and Management Agency and a code of conduct for OTEC activities.

\subsubsection{Federal-State Regulatory Mechanisms and OTEC}

\subsubsection{Current Law}

The need for a thorough assessment of the current federal offshore policies and for a federal-state relationship regarding adjacent coastal waters has been suggested earlier [197]. To deal specifically with OTEC issues, it seems desirable to outline a rough approximation of how OTEC exploitation will occur in the next 20 years. In a recent study [198], Tefft, Kelly, Dick, and Stevenson pnstulate the following selected scenario for OTEC exploitation to the year 2025:

\begin{tabular}{|c|c|c|c|c|c|c|c|c|c|}
\hline \multirow[b]{2}{*}{1980} & \multicolumn{9}{|c|}{$\begin{array}{c}\text { U.S. OTEC } \\
\text { Megawatts on Line }\end{array}$} \\
\hline & $\begin{array}{r}85 \\
.5\end{array}$ & $\begin{array}{l}90 \\
2.5\end{array}$ & $\begin{array}{r}95 \\
5\end{array}$ & $\begin{array}{l}00 \\
10\end{array}$ & $\begin{array}{l}05 \\
50\end{array}$ & $\begin{array}{r}10 \\
100\end{array}$ & $\begin{array}{r}15 \\
150\end{array}$ & $\begin{array}{r}20 \\
200\end{array}$ & $\begin{array}{r}25 \\
250\end{array}$ \\
\hline
\end{tabular}

Key Descriptors

1. Successful demonstration of economy of technology and environmental benignity of full systems by 1985 [.5 online in 85 is demonstration(s) facilities]. 
2. Federal stimulation of follow-on exploitation by:
a. establishment of benevolent legal regime
b. establishment of stimulative development institution
c. provision of substantial federal financial incentives

3. Establishment of fostering legal, institutional, and financing framework by 1880 .

4. Operations within framework to develop strategic plan for exploitation and to assemble facilities ventures concurrently with demonstration implementation; i.e., 1980 to 1985.

5. Continued operations within framework during 1985 to 2000 at a pace sufficient to establish perfected industrial, legal, institutional, and financial infrastructure by 2000. [199]

'The authors conclude that "decisive federal action will be needed to carry out this scenario," and that new federal legislation is necessary [200].

The authors offer a model of federal legislation that takes into account the necessary interface with international law as well as with state interests [201]. They propose the enactment of an "Ocean Thermal Energy Conversion, Development, Exploitation, and Regulation Act of 1980" [202], that would establish, among other policy objectives, the following: OTEC shall be subject to exclusive federal regulation; while in the short term, federal participation in OTEC development, ownership, and/or operation will be necessary to stimulate deployment to meet the established energy generation goals (by the year 2000 , a minimum of 10,000 megawatts of installed electric OTEC generation capacity usable within the United States, its territories and possessions and/or on U.S. flag vessels at sea, and of 250,000 megawatts by the year 2025) [203]. A long-term objective shall be nonfederal development, ownership, and operation.

To carry out these policies, the proposed legislation contains four titles: OTEC Development Financing Association; OTEC, Inc.; Duties and Responsibilities of the Secretary of Energy; and Legal Regime [204].

The authors provide a detailed institutional framework [205], the analysis of which is beyond the scope of this paper. However, a few selected federal-state regulatory issues will be examined here.

On the issue regarding the application of federal versus state laws to OTEC activities in adjacent offshore areas, it should be noted that extensive case law has developed regarding the applicability of the pertinent federal or state laws to injuries suffered by workers on fixed or submersible oil-drilling platforms or rigs [206]. Different rules have been applied to injuries occurring on fixed platforms within the 3-mile zone as opposed to those occurring beyond the 3-mile limit [207]. A landmark decision was a 1969 case, Rodrigue v. Aetna Casualty \& Surety Co. [208], in which the U.S. Supreme Court held that state law would apply to fixed offshore platf orms in preference to general maritime law. In 1972, the Longshoremen's and Harbor Workers' Compensation Act [209] was amended, allowing a concurrent application of both federal and state laws in case of an overlap [210]. 
However, until Congress enacts comprehensive federal legislation regarding OTEC, the guidelines on the applicable law are provided by the Supreme Court test of uniformity versus locality or diversity:

If a case falls within an area in commerce thought to demand a uniform national rule, state action is struck down. If the activity is one of predominantly local interest, state action is sustained. More accurately, the question is whether the state interest is outweighed by a national interest in the unhampered operation of interstate commerce. [211]

More recently, in Ray v. Atlantic Richfield Co. [212], the issue was that of a conflict between Washington State's tanker law regulating oil tankers in Puget Sound [213], the Ports and Waterways Safety Act of 1972 (PWSA) [214], and the Constitution. The Supreme Court found certain safety features in the design and equipment of tankers which were required under Washington law to be invalid in the face of the preempting requirements set by PWSA [215]. The Court applied the uniformity/diversity tests and based its decision on the need for uniformity of safety design requirements. Applying the same test, it also struck down another provision of Washington law, that excluded tankers in excess of 125,000 dwt [216] from Puget Sound. However, the Court upheld another provision, which required that tankers over a certain size "take a Washington State licensed pilot while navigating Puget Sound" [217], on the ground that this provision was more of an operating rule for local waters [218].

The issues of licensing, the law applicable to OTEC facilities in adjacent waters, and the potential environmental and administrative burdens upon the coastal states were addressed by DPA in the context of deepwater port facilities and have been noted earlier [219].

\subsubsection{Recommendations}

Federal and state interests coincide in a number of areas that will probably be affected by OTEC development coastal zone management and land planning, revenue sharing, state costs and fees, and electricity rate regulations. Coastal states have a significant stake because of possible conflicts with other ocean uses, adverse environmental effects, siting of shore-based support facilities, etc. Thus, it will be in the mutual interest of the Federal Government and coastal states that a mechanism he devised that is workable and feasible, effective and efficient, environmentally sound, and equitable in its reach while dealing with federal-state interests [220]. These broad policy objectives should be given effect by a system under which:

1. The licensing and regulatory authority will be the Federal Government.

2. The DOE/Federal Energy Regulatory Commission (FERC) will be the lead federal agency to license and regulate OTEC activities, similar to the Department of Transportation/Coast Guard's role as the lead agency for licensing deepwater port facilities under DPA.

3. OTEC facilities in offshore areas will be considered a utility in interstate and foreign commerce and will be subject to regulations and procedures of FERC both as to rate regulation and technical standards.

4. The Coast Guard and the Corps of Engineers will be responsible for navigational safety and seaworthiness pertaining to OTEC facilities. 
Such a scheme will accommodate federal-state interests by providing for:

1. a federal/state revenue-sharing scheme, especially permitting states to recover the economic cost to them of a federal right-of-way for transmission cables through the 3-mile territorial sea and also for shore-based facilities;

2. an effective federal/state consultative mechanism; and

3. administrative advisory boards.

\subsection{ENVIRONMENTAL CONSIDERATIONS}

A recent study has outlined the following environmental problems assnelated with the depluyment of OTEC devices in the ocean:

- the potentially toxic effect on marine life of metallic elements eroded or corroded from heat exchangers;

- the adverse effect of mixing natural thermocline and salinity gradients;

- the potentially toxic effects of working fluid seepage into the seawater or seawater into the working fluid;

- the ecological impacts of concentrations of biocides (such as chlorine) used to prevent biofouling;

- the safety of workers faced with exposure to chemicals;

- the effect on the microclimate of slightly lower air and surface temperatures around the plant. [221]

It should, however, be noted that this inquiry into the potentially adverse environmental impact of OTEC activities is speculative. Nonetheless, it is certainly desirable that these issues be addressed at this preliminary stage of OTEC development. The discussion in this section will open with a brief outline of the domestic (federal-state) issues, and will focus primarily on international aspects of OTEC-related environmental issues.

\subsubsection{Domestic (Federal-State) Issues}

Potential environmental impacts from OTFC facilities in constal waters include those from construction and operation of such facilities, cables and transmission lines, and onshore services and support facilities. The existing U.S. legislation relevant to OTEC activities both during its research and development phase and during the commercial phase includes the OCS Lands Act [222], CZMA [223], DPA [224], and the National Environmental Policy Act of 1969 (NEPA) [225]. But for NEPA, the pertinent provisions of these statutes have already been examined in the preceding sections on jurisdiction [226] and regulatory mechanisms [227]. Consequently, the discussion here will be confined to NEPA and recent developments regarding the other statutes.

NEPA requires federal agencies to prepare records on environmental effects of and alternatives to "every recommendation or report on proposals for legislation and other 
major federal actions significantly affecting the quality of the human environment" [228]. Since federal involvement in OTEC development is expected to be substantial, at least during the initial stages, preparation of programmatic Environmental Impact Statements (EIS) [229] will be required during the research phase of OTEC development. Additionally, while OTEC facilities will be subject to site-specific EIS', because of the federal time, money, or effort an OTEC facility received [230], it is possible that regional EIS' will also be needed, because of the cumulative effect of a number of OTEC facilities in a region [231].

Among other significant developments, the Coast Guard, on December 4, 1978, proposed rules for administering an offshore oil pollution compensation fund [232], that will be set up pursuant to the 1978 Outer Continental Shelf Lands Act Amendments [233], signed by President Carter on September 22, 1978 [234]. The Secretaries of Transportation and the Treasury will administer the fund, which is expected to cover "all marine oil pollution, including that discharged from onshore facilities and deepwater ports" [235]. Under the 1978 amendments [236], no license for the development and production of oil or gas on OCS will be granted unless it conforms with the requirements of CZMA [237]. Also, the Council on Environmental Quality (CEQ) is proposing new pollution cleanup plans in which coastal states' interests are recognized [238]. It is also worth noting that since the total number of coastal zone management programs stand now at 13-California, Hawaii, Maine, Maryland, Massachusetts, Michigan, New Jersey, North Carolina, Puerto Rico, Oregon, Rhode Island, Washington, and Wisconsin [239]-more active state participation in decision making can be anticipated.

\subsubsection{International Aspects}

In addition to the primary concern of the coastal state with its immediate marine environment, $i$ ts interests also extend to the protection and preservation of a shared global marine environment. The latter is affected by unilateral state actions as well as collective actions by states. Selected recent developments of states' actions that might have a bearing on OTEC development will be noted in this section, which will conclude with a brief comment on pertinent ICNT proviziono.

\subsubsection{Unilateral U.S. Actions Related to the Marine Environment}

During the recent past, the U.S. Congress has adopted legislation with potential extraterritorial reach in the marine environment. For example, the Clean Water Act [240] extended the application of Section 311 (Oil and Hazardous Substance Liability) of the Federal Water Pollution Control Act [241], to cover activities that affect the resources of the 200-mile U.S. fisheries zone or its OCS. Earlier, the Fishery Conservation and Management Act of 1976 [242] extended the U.S. fishery zone to 200 miles. Other U.S. acts with potential effect on maritime activities include the U.S. Ports and Waterway Safety Program [243], the Marine Protection Research and Sanctuaries Act (MPRSA) of 1972 [244], the new Coast Guard Regulations concerning navigational aids [245], and the DPA [246].

Under Title III of MPRSA, the Secretary of Commerce, after consultation with specified federal agencies, is authorized to "designate as marine sanctuaries those areas of ocean waters, as far seaward as the inter continental shelf . . . which he determines necessary for the purpose of preserving or restoring such areas for conservational, recreational, ecological, or esthetic values" [247]. If a proposed sanctuary would include waters within 
a state's jurisdiction, the Secretary must consult with state officials [248]. However, the governor of an involved state may veto a sanctuary designation within that state's jur isdiction, within 60 days of the notice of such designation [249]. For sanctuaries that include areas of ocean waters outside territorial waters of the United States, the Secretary of State is directed to take "appropriate" action to negotiate international agreements "to protect such sanctuary and to promote the purposes for which it was established" [250]. Prior to the promulgation of regulations to control activities within the sanctuary, the Secretary of Commerce must consult with interested federal agencies [251]. Such regulations are required to be "applied in accordance with recognized principles of international law" [252]. The Act provides that "no permit, license, or other authorization issued pursuant to any other authority shall be valid unless the Secretary [of commerce] shall certify that the permitted activity is consistent with the purposes of this chapter and can be carried out within the regulations promulgated under this section" [253]. This "consistency" requirement is similar to the federal consistency requirements of CZMA [254]. Although, MPR.SA has not been effectively utilized thus far [255], one recent study finds for it "a potentially prominent role in assuring that the nation's approach to its marine resources is both comprehensive and buluruser" [256].

The debate continues as to whether NEPA applies to major federal actions abroad [257]. The argument for its application abroad was recently made at a Senate Subcommittee hearing by Russell E. Train, former EPA administrator, former CEQ chairman, and current president of the Worldlife Fund. He asserted that House and Senate members attending a 1968 colloquium, which "served as a basis for NEPA," intended that the law apply beyond U.S. territorial limits, and that President Carter reinforced that view in his 1977 environmental message [258]. He added that an environmental policy which "failed to recognize the global nature of the human environment would be shortsighted," and that the United States should consider the "significant extraterritorial environmental impacts" of its actions [259]. However, with regard to the application of NEPA to the Export-Import Bank, (Eximbank), the concern of U.S. business is that EIS requirements for Eximbank would result in delays in getting loans and added costs to upplicants, thcreby depressing the rate of U.S. exports [260].

The controversy will be settled through an Executive Order setting out responsibilities of federal agencies for reviewing environmental effects of their overseas projects. Reportedly, under a proposed Executive Order, certain federal actions having a significant adverse effect upon the environment of nonparticipating third countries or natural resources of global importance, will be required to have abbreviated envirunmental reviews [261]. Eximbank President, John L. Moore, recently explained that the proposed Executive Order would require short environmental assessments primarily for "projects" to be financed by Eximbank [262]. Thus, if Eximbank were to finance the purchase of an OTEC plant for a developing state, an assessment would be required. It may also be noted that the Department of Energy has connissioned enviruninenlul impact assessments of a small floating OTEC test facility [263].

Since so little is yet known about OTEC activities and operations, it secms desirable that environmental assessments be conducted during the research phase. The same applies in the commercial phase, whether the OTEC plant is to operate in a U.S. coastal zone, in the coastal zone of another state, or on the high seas.

\subsubsection{Multilateral Actions}

The 1972 U.N. Conference on the Human Environment in Stockholm (the Conference) [264] acknowledged the emerging norms of state responsibility and liability for 
transnational environmental damage. Under Principle 21 of the U.N. Declaration on the Human Environment, states are responsible for insuring "that activities within their jurisdiction or control do not cause damage to the environment of other states or of areas beyond the limits of national jurisdiction" [265]. Also, under Principle 22, "States shall cooperate to develop further the international law regarding liability and compensation for the victims of pollution and other environmental damage caused by activities within the jurisdiction or control of such states to areas beyond their jurisdiction" [266]. Principle 7 calls upon states to "take all possible steps to prevent pollution of the seas by substances that are liable to create hazards to human health, to harm living resources and marine life, or to damage or interfere with other legitimate uses of the sea" [267].

Following the Stockholm conference, several conventions were concluded, including the London Convention on the Dumping of Wastes at Sea [268], the 1973 IMCO Convention on the Prevention of Pollution from Ships [269], and the 1974 Convention on the Safety of Life at Sea [270]. Also, there have been substantial bilateral and multilateral efforts to conclude new conventions for the prevention of marine pollution and the conservation and management of the marine environment [271], which might have some bearing on OTEC operations.

\subsubsection{ICNT Provisions}

Part XII of ICNT contains 46 articles dealing with the protection and preservation of the marine environment. States are obliged to protect and preserve the marine environment [272], to refrain from polluting the environment of other states or areas beyond their national jurisdiction [273], and to take measures to prevent, reduce, and control marine pollution [274]. Among specific measures, states are to minimize release of toxic, harmful, or noxious substances from dumping [275], pollution from-vessels [276], and "from all other installations and devices operating in the marine environment, in particular for preventing accidents and dealing with emergencies, ensuring the safety of operations at sea, and regulating the design, construction, equipment, operation and manning of such installations or devices" [277]. In another article ICNT calls upon states "[i]n taking measures to prevent, reduce, and control pollution of the marine environment ... not to transfer, directly or indirectly, damage or hazards from one area to another or transform one type of pollution into another" [278]. States would also assume positive legal responsibility to cooperate in international monitoring programs [279], and to assess the environmental impacts of their activities on the marine environment [280]. Article 210 deals specifically with activities in the Area:

1. International rules, standards and recommended practices, and procedures shall be established ... to prevent, reduce, and control pollution of the marine environment from activity relating to the exploration and exploitation of the Area. Such rules, standards, and recommended practices and procedures shall be reexamined from time to time as necessary.

2. ... States shall establish national laws and regulations to prevent, reduce, and control pollution of the marine environment from activities relating to the exploration and exploitation of the Area undertaken by vessels, installations, structures, and other devices flying their flag or of their registry. 
According to Article 236 on responsibility and liability, states are "responsible for the fulfillment of their international obligations concerning the protection and preservation of the marine environment [and] shall be liable in accordance with international law for damage attributable to them resulting from violations of these obligations" [281].

This segment on the ocean's environment provides stronger guarantees than ever before [282]. OTEC activities and operations would certainly be covered under many of the principles and specific provisions contained in the segment. 


\section{SECTION 3.0}

\section{CONCLUSIONS}

Since OTEC holds sufficient promise to warrant vigorous research efforts on its systems and technology [283], it is equally important that an efficient and effective legal and institutional framework be devised without any further delay. That is why a major objective of this study has been to focus on some of the most pressing aspects related to OTEC development. Accordingly, the preceding discussion addressed only selected issues and either left untouched or barely touched upon several issues, including the potential application of antitrust laws to OTEC activities [284], liability plans [285], utility policy and regulation [286], and financial arrangements and incentives including tax advantages [287] that might facilitate and expedite OTEC development.

Specific recommendations made here relate to both federal-state and international aspects. To recapitulate, on national-international issues, it is recommended that the United States accept the 200-mile coastal state competence related to OTEC siting and deployment for two reasons. First, it is unlikely that a contrary assertion, seeking freedom of OTEC activities within EEZ, will be accepted by a majority of nations at the LOS III negotiations or, in the event of the failure of LOS II to reach accords, recognized by states. Second, the United States will benefit under such coastal state competence, since major OTEC sources for the United States lie off the west coast of Florida, Hawaii, and Puerto Rico, within the zone.

It seems desirable that Congress enact as an interim measure legislation creating a 200mile Coastal Energy Conservation and Management Zone. The measure would be in line with the U.S. fishery zone and the recently established zones to enforce navigational safety rules and to control pollution. Under such a zone the United States will claim limited jurisdiction for the specific purpose of energy conservation and management. It will be an interim measure to be superseded by the legislation required to implement the EEZ provisione of the Law of the Sea Treaty when it is concluded. To engage in OTEC activities on the high seas, the United States could invoke a "reasonable use" theory. An appropriate model is provided by the Deepwater Ports Act of 1974, under which Congress specifically declared that nothing in the Act is to be construed to affect the legal status of the high scas; the superjacent airspace, or the seabed and subsoil. Thus, the deepwater port is not to "unreasonably interfere with international navigation, or other reasonable uses of the high seas ...."

On federal-state jurisdictional issues in adjacent coastal waters, the need is to devise an efficient management of the 200-mile marine zone. Who owns the extended stretch of 9 miles when the territorial limit is expanded to 12 miles-coastal states or the Federal Government-is not the crucial issue. What is important is that a cohesive U.S. policy be formed and strong institutional structures be built to implement it. The object of such a policy will be to facilitate an equitable resolution of federal-state issues. Proposals for the creation of a strengthened policy-setting body include the formation of a cabinetlevel marine affairs council, a public corporation such as COMSAT, or a public body such as Tennessee Valley Authority.

To deal with national-international regulatory issues, it is necessary that the United States pay attention now to the devising of imaginative bilateral and regional arrangements as well as to the prescription of unilaterial U.S. regulations dealing with issues related to licensing and registration, safety, conflicting sea uses, communications, 
import and export, foreign labor, insurance, liability and compensation schemes, etc. Bilateral and regional arrangements will be needed to resolve issues, such as the apparently competing interests of a coastal state and the licensing-registry state, where a foreign registered/licensed OTEC device is operating adjacent to a coastal state EEZ. These arrangements will also deal with questions arising out of bilateral or regional schemes under which a combination of a state or states and private enterprises pool their resources, technology, and know-how to enter into arrangements for research or commercial purposes, such as joint ventures to construct, operate, and own OTEC devices in a specific geographic area. Bilateral and regional consultative mechanisms will be needed to address specific issues regarding the management of conflicting claims of ocean users caused by OTEC presence. Also, dispute settlement mechanisms will have to be devised. Regarding OTEC siting in the high seas, mechanisms on a global scale might have to be devised to set standards and regulations concerning the licensing and operation, and allocation of OTEC sites, for settlement of disputes, and to insure the efficient and optimal use of the oceans for OTEC development.

On federal-state repulatory issues, it will be necessary to cstablish a moohanium under whlch the licensing and regulatory authority will be the Federal Government, while the DOE/Federal Energy Regulatory Commission (FERC) will be the lead federal agency to license and regulate OTEC activities. OTEC facilities in offshore areas will be considered a utility in interstate and foreign commerce and will be subject to regulations and procedures of FERC both as to regulations and technical standards. The Coast Guard and the Corps of Engineers will be responsible for navigational safety and seaworthiness pertaining to OTEC facilities. An accommodation of federal-state interests will be provided by effective federal-state consultative mechanisms, administrative advisory boards, and federal-state revenue sharing schemes.

On environmental issues, in the domestic arena, NEPA requirements of environmental impact statements will be applicable. Also, the requirements of the Coastal Zone Management Act will apply. In the international arena, in addition to the possible applicability of EIS requirements, several existing multilateral agreements and ICNT provisions will apply.

It seems essential that a comprehensive management system for U.S. coastal areas be devised, that requires comprehensive ocean management legislation. In the international arena, it may not be too early to consider the drafting of a convention that mandates environmental impact assessments of a statc's major projects that could harm the environment of another state or the shared global environment, and provides for consultative mechanisms [288]. This should be followed by the drafting of another convention specifically dealing with OTEC activities, as well as a code of conduct. Even if these tasks appear to be overwhelming, it is imperative that they be undertaken now. 


\section{REPERENCES}

1. Cited in Council on Environmental Quality, Solar Energy-Progress and Promise 1 (1978).

2. Reported in Den. Post, November 23, 1978, at 38, col. 1 .

3. See, e.g., Nye, Jr. Nuclear Policy: Balancing Nonproliferation and Energy Security, 78 Dept. State Bull., October 1978, at 39. See also 78 Dept. State Bull., September 1978, at 3.

4. Energy Policy and Planning, Executive Office of the President, The National Energy Plan (U.S. Govt. Printing Office, April 1977).

5. Whitmore, OTEC: Electricity from the Ocean, 81 Technology Rev., October 1978, at 58-60. However, contra opinion has been expressed. See, e.g., Report of the Special Committee on Energy Law, 10 Natural Res. Law. 655, 671:

Unfortunately many advocates of alternative energy sources overstate their potential, thus defeating their own purpose. It is unrealistic to expect these alternative sources to replace conventional ones in the foreseeable future, but it is just as unrealistic not to recognize their value as important components of future energy budgets.

6. Id. at 58 .

7. Id. at 61. However, contra opinion has been expressed. See, e.g., letter from Phil Key (SERI) to George Morgan: "From a technical standpoint, this is more than a design scale-up to support operational units." (Letter is on file with the author.)

8. Id. at 63 .

9. On technical, economic, and financial aspects, see generally H. Knight, J. Nyhart \& R. Stein, Ocean Thermal Energy Conversion (1977) [hereinafter cited as Knight, Nyhart \& Stein]; Science Policy Research Division, Congressional Research Service, Subcomm. on Advanced Energy Technologies and Energy Conservation Research, Development and Demonstration of the House Comm. on Science and Technology, 95th Cong. 2d Sess., Energy from the Ocean 25-79 (Comm. Print 1978); E. Francis, Investment in Commercial Development of Ocean Ther mal Energy Conversion (OTEC) Plant-Ships (1977) (Prepared by Johns Hopkins University Applied Physics Laboratnry for U.S. Dept. of Commerce); Solar Energy Research Institute, Economic Feasibility and Market Readiness of Eight Solar Technologies: Interim Draft Report 130-45 (1978) (Prepared for U.S. Dept. of Energy) [hereinafter cited as SERI Interim Draft Rep.]; R. Tefft, R. Kelly, C. Dick, Jr., \& K. Stevenson, Toward a Legal, Institutional and Financial Framework for OTEC Demonstration and Commercialization (1978) (Prepared for ERDA by Tefft, Kelly and Motley, Inc.) [hereinafter cited as Tefft, Kelly \& Motley, Inc. Study]; B. Washom \& J. Nilles, Incentives for the Commercialization of Ocean Thermal Energy Conversion Technology (OTEC) (1977) (Prepared for RANN, Nat'l Sci. Found.); J. Witwer, J. Alich, S. Kohan, M. Levine, P. Meagher, E. Pickering, F. Schooley, A. Slemmons, \& T. Thompson, 1 A Comparative 
Evaluation of Solar Alternatives, Implications for Federal RD\&D 95-101 (1978) (Submitted to Solar Working Group, U.S. Dept. of Energy); and 5 Sharing the Sun: Solar Technology in the Seventies 392-548 (K. Boer ed. 1976). Cohen \& Dunning, An Island Strategy for OTEC Commercialization (Preprint of Invited Paper for Solar Energy and Conservation Symposium Workshop, Miami, Florida, 11-13 Dec. 1978).

10. The Conference which began in Caracas in 1974 concluded its resumed seventh session on September 15, 1978, and will convene its eighth session in Geneva on March 19, 1979. For a short report on the latest session, see 15 UN Monthly Chronicle, September 1978, at 41-42. Voluminous legal literature has grown around the Conference issues. See, e.g., various publications of the Law of the Sea Institute including the papers and proceedings of its annual conferences, and its occasional and specinl papers; 1-6 New Directione in the Law of the Sea (R. Churchill, M. Nordquist, S. Lay, K. Simmonds \& J. Welch eds. 1973-77); R. Dupuy, The Law of the Sea: Current Problems (1974); S. Oda, The Law of the Sea in Our Time (1977); The Law of the Sca: Issues in Ocean Resource Management (D. Walsh ed. 1977); Symposia in volumes 6-15 of San Diego L. Rev., 6 id. at 339-513 (1969); 7 id. at 371-673 (1970); 8 id. at $453-747$ (1971); 9 id. at

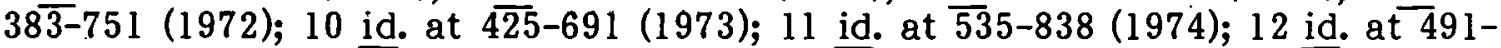
742 (1975); 13 id. at $483-778$ (1976); 14 id. at 507-750 (1977); 15 id. at 357-662 (1978).

11. The assessment is based on a study of sources cited in note 9 supra.

12. Cited in Tefft, Kelly \& Motley, Inc. Study, supra note 9 , at 3 .

1.3. Cited in id.

14. 15 UN Monthly Chronicle, September 1978, at 41-42.

15. The following four conventions were concluded at the 1958 Law of the Sea Conference in Geneva: Convention on the Continental Shclf, done at Geneva, April 29, 1958, 15 U.S.T. 471 , T.I.A.S. No. 5578, 499 U.N.T.S. 312 (effective June 10, 1964, hereinafter cited as the Continental Shelf Convention); Convention on Fishing and Conservation of the Living Resources of the High Seas, done at Geneva, April 29, 1958, 17 U.S.T. J38, T.I.A.S. No. 5969, 558 U.N.T.8. 285 (effective March 20, 1966, hereinafter cited as the Fishery Convention); Convention on the High Seas, done at Goneva, April 29, 1958, 13 U.S.T. 2312, T.I.A.S. No. 5200, 450 U.N.T.S. 82 (effective September 30, 1962) (hereinafter cited as the High Seas Convention]; Convention on tlie Terrilurlul Sea and the Contiguous Zone, done at Geneva, April 29, 1958, 15 U.S.T. 1606, T.I.A.S. No. 5634,516 U.N.T.S. 205 (effective September 10, 1964) [hereinafter cited as the Territorial Sea Convention].

16. See generally arts. 1-13 of the Territorial Sea Convention; M. McDougal \& W. Burke, The Public Order of the Oceans 174-304, 146-564 (1962) [hereinaf tel ciled as McDougal \& Burke]; Baty, The Three-Mile Limit, 22 Am. J. Int'l L. 503 (1928); Kent, The Historical Origins of the Three-Mile Limit, 48 Am. J. Int'l L. 537 (1954).

17. Arts. 14-23 of the Territorial Sea Convention. 
18. See Conference for the Codification of International Law, Bases of Discussion, League of Nations Publication C. 74. M. 39. 1929. V.

19. See United Nations Conference on the Law of the Sea, Official Records (7 Vols.), U.N. Doc. A/CONF. 13 (1958).

20. See Second United Nations Conference on the Law of the Sea, Summary Records of Plenary Meetings and of the Meetings of the Committee of the Whole, Annexes and Final Act, U.N. Doc. A/CONF. 19/8 (1960). Extensive literature exists on the 1958 and 1969 Law of the Sea Conferences. For a most comprehensive and thorough study of the various issues discussed in the conferences, see McDougal \& Burke. See also C. Colombos, The International Law of the Sea ( $\overline{6 t h}$ ed. 1967) [hereinafter cited as Colombos]; D. Bowett, The Law of the Sea (1967); Dean, The Geneva Conference on the Law of the Sea: What was Accomplished, 52 Am. J. Int' L L. 607 (1958); Dean, The Second Geneva Conference on the Law of the Sea: The Fight for Freedom of the Seas, 54 id. at 751 (1960) Fitzmaurice, Some Results of the Geneva Conference on the Law of the Sea, 8 Int'l \& Comp. L. Q. 73 (1959); Nanda, Some Legal Questions on the Peaceful Uses of Ocean Space, 9 Va. J. Int'I L. 343 (1969).

21. See note 15 supra.

22. Art. 24(2) of the Territorial Sea Convention.

23. This is in view of the distinction drawn between art. 24(1)(a) and 24(1)(b) of the Convention pertaining to a coastal state's right to take preventive or punitive measures by the infringement of domestic regulations.

24. Historically, there has been no freedom of scientific research within the territorial sea. On marine scientific research see generally $W$. Burke, Scientific Research Articles in the Law of the Sea Informal Single Negotiating Text (Occasional Paper no. 25, Law of the Sea Institute, University of Rhode Island, June 1975); Freedom of Oceanic Research (W. Wooster ed. 1973); Winner, Science, Sovereignty, and the Third Law of the Sea Conference, 4 Ocean Dev. \& Int'l L. 297 (1977); Wooster, Some Implications of Ocean Research, id. at 39.

25. Arts. 1 and 2 of the Territorial Sea Convention.

26. See Document prepared by U.N. Secretariat, Survey of National Legislation Concerning the Seabed and the Ocean Floor, and the Subsoil thereof, Underlying the High Seas Beyond the Limits of Present National Jurisdiction, U.N. Doc. A/AC.135/11 and A/AC./135/11/Add.V (1968).

27. U.N. Third Conference on the Law of the Sea, Informal Composite Negotiating Text from the Sixth Session, U.N. Doc. A/CONF. 62/WP. 10 \& Corr. 1-3 (1977) [hereinaf ter cited as ICNT].

28. Id. art. 3 .

29. Id. art. 33 .

30. Id. art. 2 .

31. Id. arts. 17-32. 
32. U.N. Third Conference on the Law of the Sea, Informal Composite Negotiating Text-Explanatory memorandum by the President, U.N. Doc. A/CONF. 62/WP. 10/Add. 1 (1977), reprinted in 16 Int'l Legal Materials 1099, 1100 (1977).

33. See generally D. Johnston \& E. Gold, The Economic Zone in the Law of the Sea: Survey, Analysis and Appraisal of Current Trends (Occasional Paper No. 17, Law of the Sea Institute, University of Rhode Island, June 1973); Alexander \& Hudy'sur, The Impact of the 200-Mile Economic Zone on the Law of the Sea, 12 San Diego L. Rev. 569 (1975); Kronfol, The Exclusive Economic Zone: A Critique of Contemporary Law of the Sea, 9 J. Mar. L. \& Comm. 461 (1978); Hollick, The Origins of the 200-Mile Offshore Zones, 71 Am. J. Int'l L. 494 (1977); Phillips, Exclusive Economic Zone as a Concept in International Law, 26 Int'l \& Comp. L. Q. 585 (1977).

34. ICNT, art. 57 .

35. Id. art. 56(1)(a).

36. Id. art. 56(b).

37. Id. art. 58(1).

38. Pres. Proc. No. 2267, 3 C.F.R. 67 (1943-48 Compilation), See generally Hollick, U.S. Oceans Policy: The Truman Proclamations 17 Va. J. Int'l L. 23 (1977).

39. See agreement between Chile, Peru, and Ecuador, August 1952, Declaration on the Maritime Zone, art. 3 (II), U.N. Legislative Series, Laws and Regulations of the Regime of the Territorial Sea 723-27 (1957). See generally B. MacChesney, Situation, Documents and Commentary on Recent Developments in the International Law of the Sea, 1956, at 264-94, 448, 455-56, 486-87 (1957); R. August, The Continental Shelf: The Practice and Policy of the Latln American States with Special Reference to Chile, Ecuador and Peru 187-203 (1960); F. Garcia Amador, Latin American and the Law of the Sea (Occasional Paper No. 14, Law of the Sea Institute, University of Rhode Island, July 1972). In 1966, Argentina extended by decree (Law No. 17, 094-M. 24, Buenos Aires, 29 December 1966) promulgated that "the sovereignty of the Argentine nation shall extend over the sea adjacent to its territory for a distance of 200 nautical miles measured from the line of the lowest tide." U.N. General Assembly, Ad Hoc Committee to study the peaceful uses of the seabed and the ocean floor beyond the limits of national jurisdiction, 2d Sess., Survey of National Legislation Conccrning the Seabed and the Ocean Floor, and the Subsoil thereof, Underlying the High Seas Beyond the Timits of Present National Jurisdictiun 7-8, U.N. Doc. $\overline{\mathrm{A}} / \mathrm{AC} / 135 / 11$ (1968).

40. See Arctic Waters Pollution Prevention Act of 1970, Can. Rev. Stat. c. 2, at 3-25 (1st Supp. 1970).

41. Organization of African Unity: Declaration on the Issues of the Law of the Sea, U.N. Doc. A/AC.138/86 (1972). See also U.N. Docs. A/AC.138/79 (1972); A/CONF. 62/33 (1974).

42. The 1972 Declaration of Santo Domingo is contained in U.N. Doc. A/AC.138/80 (1972). 
43. See note 15 supra.

44. Art. 1 of the Continental Shelf Convention. The Convention left the legal definition of the continental shelf, a compromise formula, open-ended-up to a depth of 200 meters, or a technologically exploitable distance.

45. Id. art. 2 .

46. Id. art. 3 .

47. Id. art. 5(8). Although it adds that the coastal state "shall not nor mally withhold its consent" if a qualified institution makes a request, it grants the coastal state the right "if it so desires, to participate or to be represented in the research, and that in any event the results shall be published."

48. Based on arts. 4-5 of the Continental Shelf Convention, Knight makes this argument in Knight, International Jurisdiction Issues Involving OTEC Installations, in Knight, Nyhart \& Stein supra note 9, at 45-73.

49. ICNT, art. 76 .

50. Id. arts. 77-85.

51. See, e.g., id. arts. 243-53.

52. Cited in Colombus at 51 .

53. U.S. v. Louisiana, 363 U.S. 1, 33-34 (1959) [Footnotes in the opinion omitted].

54. See Colombus at 60-61.

55. Art. '2 of the High Seas Cuivention. See notc 15 Eupra.

56. The Deepwater Port Act of 1974, 33 U.S.C. \$\$ 1501-24 (1976) [hereinafter cited as DPA]. For legislative history and purpose see [1974] U.S. Code Cong. and Ad. News 7529. See generally Krueger, Nordquist, \& Wessely, New Technology and International Law: The Case of Deepwater Ports, $17 \mathrm{Va}$. J. Int'l L. 597 (1977); Comment, Territorial Status of Deepwater Ports, 15 San Diego L. Rev. 603 (1978); Note, The Regulation of Deepwater Ports, 15 Va. J. Int'1 L. 927 (1975).

57. See Hearings on S.1751 and S.2232 before the Special Joint Subcomm. on Deepwater Ports Legislation of the Senate Comm. on Commerce, Interior and Insular Affairs, and Public Works, 93d Cong., 1st Sess., pt. 1, 606-19 (1973) (Statement of John Norton Moore).

58. See generally H. Van Panhuys, The Role of Nationality in International Law (1959); Brownlie, Relations of Nationality in Public International Law, 39 Brit. Y.B. Int 7 L. 284 (1963); McDougal, Lasswell \& Chen, Nationality and Human Rights: The Protection of the Individual in External Arenas, 83 Yale L. J. 900 (1974);

59. For a recent commentary, see LaQue, Different Approaches to International Regulation of Exploitation of Deep-Ocean Ferromanganese Nodules, $15 \underline{\text { San }}$ 
Diego L. Rev. 477 (1978). See also Charney, The International Regime for the Deep Seabed: Past Conflicts and Proposals for Progress, 17 Harv. Int'l L. J. 1 (1976); Note, A New Combination to Davy Jones' Locker: Melee over Marine Minerals, 9 Loy. Chi. L. J. 935 (1978).

60. G. A. Res. 2749,25 U.N. GAOR, Supp. (No. 28) 24, U.N. Doc. A/8028 (1970) (Adopted by a vote of 108 to 0 , with 14 abstentions. The United States voted for its adoplion.).

61. ICNT, art. 1(1).

62. Id. art. 136 .

63. Id. art. 137(1).

64. Id. art. 135.

65. Id. arts. 1(3), 133(a).

66. Id. arts. 143-49.

67. Id. art. 133(b).

68. Id. Anncx II.

69. Id. art. 133(c)(1).

70. Knigh 1 , OTEC and the Law of the Sea: The Jurisdictional Problems, in American Society of International Law, International, Legal, Political and Institutional Aspects of OTEC Demonstration and Development 15 (Study prepared for ERDA, Seplember 1978) (hereinaf ter cited as ASiL Study].

71. Knight acknowledges this possibility: "It is therefore not only conceivable but likely that if sufficient information were presented in international fora to indicate that OTEC and similar energy-producing devices might be substantial suurces of economic wealth or political leverage, underdeveloped countries would move either in LOS/3 or in another for um to seek a regulatory r'egime governing such activities beyond the exclusive economic zones of coastal states." Id. at 15.

72. ICNT, art. 135 .

73. See, e.8., The Maltese Draft, a working paper introduced by the Delegation of Malta in the United Nations seabed committee in 1971, Draft Ocean Space Treaty-Working Paper Submitted by Malta, in Report of the Committee on the Peaceful Uses of the Seabed and the Ocean Floor Beyond the Limits of National Jurisdiction, 26 U.N. GAOR, Supp. (No. 21) 105, U.N. Doc. A/8421 (1971), which treats "international oceun space," the area beyond clearly defined limits of national jurisdiction, as a unitary concept, encompassing seabed, water column, and surface, the whole constituting the "common heritage of mankind." Id. pt. IV (emphasis added).

74. ICNT, art. 143(1). 
75. See notes 65-67 supra and the accompanying text.

76. Fishery Conservation and Management Act of 1976, Pub. L. No. 94-265, 90 Stat. 33,16 U.S.C. $\$ \$ 1801-82(1976)$.

77. 33 U.S.C. S\$ 151-232 (1976), prescribe the enforcement of navigational safety rules.

78. See Clean Water Act of 1977, Pub. L. No. 95-217, 91 Stat. 1593-94, $\$ 58(a)-(c)$ amending 33 U.S.C. $\$ 1321$ (1976).

79. 33 U.S.C. $\$ \$ 1501-24$ (1976).

80. Id. $\$ 1501$ (b).

81. Id. $\$ 1521(2)$.

82. Id. $\$ 1503(\mathrm{c})(4)$.

83. Id. $\$ 1509(d)(1)$.

84. Id. $\$ 1504(\mathrm{~b})(2)$. The regulations are to be subject to recognized principles of international law. Id. $\$ 1509(3)$.

85. Id. $\$ 1505(\mathrm{a})(3)$.

86. Id. $\$ 1503(\mathrm{~h})$.

87. For a thorough and incisive study of federal-state issues in the U.S. coastal waters, see M. Ball, Law of the Sea: Federal-State Relations and the Extension of the Territorial Sea (The Dean Rusk Center for International and Comparative Law, Univorsity of Genrgia, Monograph No. 1, 1978) [hereinafter cited as $M$. Ball].

88. See note 38 supra.

89. See 13 Dept. State Bull. 484 (1945).

90. See, e.g., U.S. v. Louisiana 339 U.S. 699 (1950); U.S. v. Texas, 339 U.S. 707 (1950); U.S. v. California, 332 U.S. 19, 38-39 (1947).

91. See, e.g. E. Bartley, The Tidelands Oil Controversy 68-74, 88 (1953); Krueger, The Development and Administration of the Outer Continental Shelf Lands of the United States, 14 Rocky Mtn. Mineral L. Inst. 643, 674-77 (1968); Comment, Jurisdiction Over the Seabed: Persistent Federal-State Conflicts, 12 Urban L. Ann. 291 (1976).

92. 43 U.S.C. SS 1301-1315 (1970). For legislative history and purpose of the Act, see [1953] U.S. Code Cong. \& Ad. News 1385.

93. 43 U.S.C. $\$ 1311($ (a),(b) (1970).

94. Id. $\$ 1311(\mathrm{~d})$. 
95. Id. $\$ 1314(a)$.

96. See Organized Village of Kake v. Egan, 174 F. Supp. 500 (D. Alas, 1959).

97. U.S. Const., art. I, $\$ 8$ empowers Congress to regulate all aspects of foreign commerce.

98. See Zabel v. Tabb, 430 F.2d 199 (5th Cir. 1970), cert. denied, 401 U.S. 910 ; U.S. V. Rands, 389 U.S. 121,127 (1967).

99. See, e.g., Douglas v. Seacoast Products, Inc., 431 U.S. 265, 283-87 (1977).

100. See, e.g., Ray v. Atlantic Richfield Co., 98 S. Ct. 989 (1978).

101. 43 U.S.C. $\$ \$ 1331-43$ (1970). For legislative history and purpose of the $\Lambda$ et, sec [1953] U.S. Code Cong. \& Ad. News 2177.

102. 43 U.S.C. $\$ 1332(1970)$.

103. Id. \$ $1332(\mathrm{~b})$.

104. Id. $1333(a)(1)$.

105. Id. $\$ 1333(\mathrm{a})(2)$.

106. Id. $\$ 1333(\mathrm{e})(1)$.

107. Id. \$ $1334(\mathrm{a})(1)$.

108. Id. \$ $1333(\mathrm{f})$.

109. Id. $\$ 1333(\mathrm{a})(2)$.

110. 43 U.S.C.A. \$ 1333(2) (Supp. 1978).

111. 420 U.S. 515 (1975).

112. Id. at $522-23$.

113. The board's function is to advise the Secretary of the Interior on matters of discretionary authority under the OCS Lands Act. See U.S. Dept. of the Interior, Geological Survey, Policies, Practices and Responsibilities for Safety and Environmental Protection in Oil and Gas Operations on the Outer Continental Shelf 5 (1977), cited in M. Ball, supra note 87, at $42 \mathrm{n} .159$.

114. 43 Fed. Reg. 3883 (1978) (to be codified at 30 C.F.R. $\$ 250.34$ ); 43 Fed. Reg. 3887,3889 (1978) (to be codified at 30 C.F.R. $\$ 252$ ); 43 Fed. Reg. 3895 (1978) (to be codified at 30 C.F.R. $\$ 3301.8)$.

115. President Carter signed the 1978 Outer Continental Shelf Lands Act Am endments on September 22, 1978, Pub. L. No. 95-372, 92 Stat. 629.

116. Id. Title II, $\$ 208$ (adding a new $\$ 19$ ), 92 Stat. 652-53. 
117. See, e.g., The Federal Water Pollution Control Act (FWPCA), 33 U.S.C. $\$ \$ 1251-$ 1376 (1976), as amended by The Clean Water Act of 1977, Pub. L. No. 95-217, 91 Stat. 1566; The Fishery Conservation and Management Act (FCMA), Pub. L. No. 94-265, 90 Stat. 331 (codified in several sections of 16 \& 22 U.S.C., the Act provides for the participation of states' representatives on Regional Fisheries Management Councils (16 U.S.C. \$ 1852 (1976)); Marine Protection, Research and Sanctuaries Act of 1972, 16 U.S.C. \$\$ 1401-34 (1976); The Endangered Species Act, 16 U.S.C. $\$ \$ 1531-43$ (1976); and The Marine Mammal Protection Act, 16 U.S.C. $\$ \$ 1361-1407$ (1976).

118. 33 U.S.C. $\$ \$ 1501-24$ (1976).

119. 16 U.S.C. \$\$ 1451-64 (1976).

120. 33 U.S.C. $\$ 1504(a),(b)(1976)$.

121. Id. $\$ 1503(\mathrm{c}),(\mathrm{d}),(\mathrm{e})$.

122. Id. $\$ 1502(10)$.

123. See 33 U.S.C. $\$ 403$ (1976).

124. 33 U.S.C. $\$ 1500$ (b) (1976).

125. Id. $\$ 1503(\mathrm{c})(9)$.

126. Id. $\$ 1508(\mathrm{a})(1)$.

127. Id. $\$ 1508(\mathrm{a})(2)$. The regulations implementing the Act are contained in 33 C.F.R. \$ 148 (1977).

128. 33 U.S.C. $\$ 1504(h)(2)(\mathrm{i})(2)(\mathrm{A})(1976)$.

129. Id. $\$ 1503(\mathrm{f})$.

130. Id. $1518(\mathrm{~b})$.

131. Id. $\$ 1504(\mathrm{~h})(2)$.

132. Id.

133. See generally Hollings, Congress and Coastal Zone Management, Coastal Zone Management J. 115 (1973); Knecht, Coastal Zone Management-A Federal Perspective, id. at 123; Zile, A Legislative Political History of the Coastal Zone Management Act of 1972 , id. at 235; Symposium-Implementation of the Coastal Zone Management Act of 1972,16 Wm. \& Mary L. Rev. 717-822 (1975).

134. 16 U.S.C. $\$ 1456(c)(1),(2)(1976)$.

135. 16 U.S.C. $\$ \$ 1453(4)(\mathrm{i}), .1456(\mathrm{c})(3)(\mathrm{B})(1976)$.

13G. See 15 C.F.R. pt. 923 (1978). For NOAA regulations implementing the consistency provisions, see 43 Fed. Reg. 10510-33 (1978) (to be codified al 15 C.F.R. pt. 930). 
137. 16 U.S.C. $\$ 1456(\mathrm{a})(1976)$.

138. See id. \$\$ 1456(a),(c),(d), 1464(b). See generally Hildrelth, The Operation of the Federal Coastal Zone Management Act as Amended, 10 Nat. Resources Law. 211, 221-23(1977).

139. See Hildreth, supra note 138 , at $222-23$.

140. 43 U.S.C. S\$ 1331-43 (1970).

141. 33 U.S.C. \$\$ 1501-24 (1976).

142. M. Ball, supra note 87 , at $23-24$.

143. See id. at 54-55.

144. For a concise report on these activities, see A. Wilson, U.S. Ocean Policy: Coordination and Control, 1 Marine Policy Reports, No. 6 (Center for the Study of Marine Policy, College of Marine Studies, University of Delaware, September 1978).

145. See id. at 2 .

148. Introduced in U.S. Senate on October 20, 1977. Hearings were held on April 6, 1978.

147. A. Wilson, supra note 144 , at 4 .

148. NACOA made this recommendation in .Iıne 1977. Id. at 3.

149. See M. Ball, supra note 87 , at 56-57.

150. See generally Nyhart, OTEC Etructures üs Vessels, In ASIL Study, supra note 70, at 213-33. See also Nanda, The Legal Status of Surface Devices Functioning at Sea Other than Ships (Drilling Rigs, Offshore Platforms, etc.), 26 Am. J. Comp. L. (Supp.) $233(1978)$.

151. See, e.g. on ship mortgages, 46 U.S.C. \$\$ 911-84 (1970); subchapter XI, "Federal Ship Mortgage Insurance," of the Merchant Marine Act of 1936, 46 U.S.C. \$\$ 1271-80 (1970 \& Supp. IV 1974), as amended by the Federal Ship Financing Act of 1972, Pub. L. No. 92-507. See generally Smith, Jr., Ship Mortgages, 47 Tul. L. Rev. 608 (1973). On subsidles and tax advantages, see subchapters $V$ and VI of The Merchant Marine Act of 1936, 46 U.S.C. \$\$ 1151-83(a) (1970 \& Supp. IV 1974), as amended by The Negotiated Shipbuilding Contracting Act of 1976, Pub. L. No. 94-373 \$S 2,3,90 Stat. 1042; Internal Revenue Code, 26 U.S.C. $\$ 861(\mathrm{e})$ (1976). See generally Cook, Jr., Government Assistance in Financing Title XI Federal Guarantees, 47 Tul. L. Rev. 653 (1973); Kominers, Federal Government Aids to Merchant Shipping, id. at 691 .

152. Article II (2), International Convention relating to Intervention on the High Seas in Cases of Oil Pollution Casualties, done November 29, 1969, 2S U.S.T. 765, T.I.A.S. No. 8068, reprinted in 9 Int'l Legal Materials 25 (1970) (entered into force May 6, 1975). 
153. Convention on the Prevention of Marine Pollution by Dumping of Wastes and other Mattcr, done December 29, 1972, 26 U.S.T. 2403, T.I.A.S. No. 8165 (entered into force August 30, 1975).

154. Id. art. III(2).

155. Id. art. $\operatorname{VII}(1)(\mathrm{c})$.

156. International Convention for the Prevention of Pollution from Ships, done November 2, 1973, reprinted in 12 Int'l Legal Materials 1319 (1973).

157. Id. art. 2(4).

158. Id. art. 3(1).

159. Convention on the International Maritime Satellite Organization, done September 3, 1976, reprinted in 15 Int'l Legal Materials 1051 (1976).

160. Id. art. $1(f)$.

161. These conventions include: International Convention for the Safety of Life at Sea, (SOLAS Convention), signed June 17, 1960, 16 U.S.T. 185, T.I.A.S. No. 5780, 536 U.N.T.S. 27; 1974 SOLAS Convention, reprinted in 14 Int'l Legal Materials 959 (1975); International Convention for the Prevention of the Sea by Oil, opened for signature May 12, 1954, 12 U.S.T. 2989, T.I.A.S. No. 4900, 327 U.N.T.S. 3, as amended by Amendments to the International Convention for the Prevention of the Sea by Oil, done April 11, 1962, 17 U.S.T. 1523, T.I.A.S. No. 6109, 600 U.N.T.S. 332; International Convention on Load Lines, done April 5, 1966, 18 U.S.T. 1857, T.I.A.S. No. 6331, 640 U.N.T.S. 133; and International Convention on Civil Liability for Oil Pollution Damage, done November 29, 1969, reprinted in 9 Int'l Legal Materials 45 (1970).

162. ICNT art. $1(1)(5)(a)(i \&$ ii).

163. Id. art. 195(3)(c \& d). The provisions cover all installations and devices in the ir arine environment.

164. Id. art. $210(2)$.

165. See generally Faron, International Regulatory Aspects of OTEC Development and Operation, in ASI Study, supra note 70, at 86-148.

166. See generally J. Barros \& D. Johnston, The International Law of Pollution (1974); Nanda, The Establishment of International Standards for Transnational Environmental Injury, 60 Iowa L. Rcv. 1089 (1975).

167. See generally Nanda, supra note 166, at 1101-08, 1126-27; note 168 infra; Okidi, Toward Regional Arrangements for Regulation of Marine Pollution, 4 Ocean Dev. \&Int'l C. 1 (1977).

168. See International Center, Industry and Environment, Executive Report No. 30, October 30, 1978. UNEP has established a special Regional Seas Programme Activity Center at its Geneva office. 
169. Art. 2 of the High Seas Convention, note 15 supra.

170. See notes 56-57 supra and the accompanying text.

171. Id.

172. The High Seas Convention, supra note 15, arts. 26-29.

173. Id. arts. 24-25.

174. See supra note 15.

175. Id. art. 4.

176. Id. art. 3.

177. Id. art. 5(1).

178. Id.

179. See notes 43-51 supra and the accompanying text.

180. See generally B. Boczek, Flags of Convenience (1962); McDougal \&. Burke, supra note 16 , at $1008-1140$.

181. In addition to the series cited in note 59 supra, see generally Burton, Freednm of the Seas: International Law Applicable to Deep Seabed Mining Claims, 29 Stan. L. Rev. 1135 (1977); Charney, Law of the Sea: Breaking the Deadlock, 55 For: Aff. 598 (1977); Galey, From Caracas to Geneva to New York: The International Seabed Authority as a Creator of Grants, 4 Ocean Dev. \& Int'l L. 171 (1977).

182. Supra note 181 .

183. See notes $150-64$ supra and the accompanying text.

184. Faron, supra note 165 , at $96-97$ (footnotes omitted).

185. See notes $240-72$ infra and the accompanying text.

186. See generally G. Gill, F. Becker \& T. Sofer, The Wreck of the Torrey Canyon (1967); Nanda, The Torrey Canyon Disaster: Some Legal Aspects, 44 Den. L. J. 400 (1967).

187. Supra note 161 .

188. Supra note 152 .

189. Supra note 156 .

190. ICNT arts. 154-92.

191. Id. art. 136. 
192. See id. pt. XI (arts. 154-92) and Annexes II \& III.

193. See id. pt. XII (arts. 193-238).

194. See generally Colino, International Cooperation between Communications Satellite Systems: An Overview of Current Practices and Future Prospects, 5 J. Space L. 65 (1977); Frutkin, Direct Community Broadcast Projects Using Space Satellites 3 id. at 17 (1975).

195. See generally National Legislation and Treaties Relating to the Law of the Sea 573-86 (U.N. Legislative Series 1976), U.N. Doc. ST/LEG/SER.B/18.

196. See generally Nanda, supra note 166, at 1101-08.

197. See notes 142-49 supra and the accompanying text.

198. Tefft, Kelly \& Motley Study, supra note 9.

199. Id. at 8 .

200. Id.

201. Id. at 11-24.

202. Id. at 10 .

203. Id. at 11 .

204. Id. at 12 .

205. Supra note 201; Teff $t$, Kelly \& Motley, Inc., Working Draft, OTEC Development, Exploitation, and Regulation Art of 1980 (1978).

206. For discussion of these cases, see Comment, Offshore Oil Platforms and Admiralty Law: Rodrigue in Retrospect, 49 Tul. L. Rev. 65 (1975).

207. Id.

208. 395 U.S. 352 (1969).

209. Pub. L. No. 92-576, 86 Stat. 1251 (1972), 33 U.S.C. $\$ \S 901-50$ (1976).

210. See Comment, Broadened Coverage Under the LHWCA, 33 La. L. Rev. 683 (1973).

211. Calif ornia v. Zook, 336 U.S. 725, 728 (1949).

212. $98 \mathrm{~S} . \mathrm{Ct} .988(1978)$.

213. Wash. Rev. Code Ann. \$ 88.16.170-190 (Supp. 1978).

214. 33 U.S.C. $\$ \$ 1221-27,46$ U.S.C. 391 (a) (Supp. V 1975). The provision on safety features held invalid is Wash. Rev. Code Ann. $\$ 88.16 .190$ (2) (Supp. 1978). 
215. 98 S.Ct. at $996-1000$.

216. Wash. Rev. Code Ann. $\$ 88.16 .190$ (1) (Supp. 1978).

217. Wash. Rev. Code Ann. \$88.16.180 (Supp. 1978).

218. 98 S.Ct. at 1000-1002.

219. See notes 120-32 supra and the accompanying text.

220. See generally supra note 205 .

221. SERI Interim Draft Rep., supra note 9, at 137-39.

222. 43 U.S.C. $\$ \$ 1331-43(1970)$.

223. 16 U.S.C. S\$ 1451-64 (1976).

224. 33 U.S.C. $\$ \$ 1501-24$ (1976).

225. 42 U.S.C. $\$ \$ 4321-47$ (1976).

226. See notes 92-141 supra and the accompanying text.

227. See notes 206-20 supra and the accompanying text.

22.8, 42 U.S.C. $\$ 4332(\mathrm{c})$. 3ee generally R. Linoff, A National Policy for the Fnvirnnment: NEP $\Lambda$ and it 3 Af termall (1976).

229. See generally Note, The Scope of the Program EIS Requirement: The Need for a Coherent Judicial Approach, 30 Stan. L. Rev. 767 (1978).

230. Actions with direct effect as well as actions with indirect effects have been held subject to EIS requirements. Since federal agencies are required to make a detailed statement on "major federal actions significantly affecting the quality of the human environment," the question regarding the scope of "major federal actions" assumes special importance. For a criticism of $n$ hroad interpietution of the term thereby requiring EIS' for actions which may not be "major federal actions," see Friedman, The National Environmental Pulicy Act of I96y--'The Brave New World of Environmental Legislation, 6 Natural Res. Law, 44 (1973).

231. For a discussion of regional EIS', see Kleppe v. Sicrrn Club, 427 U.S. 390 (1976) rev'g Sierra Club v. Morton, 514 F. 2d 856 (D.C. Cir. 1975).

232. 43 Fed. Reg. 56840 (1978). See 9 Environ. Rep. (BNA) 1413 (1978).

233. Pub. L. No. 95-372, 92 St.at. 629 (1978).

234. See 9 Environ. Rep. (BNA) 972 (1978).

235. 43 Fed. Reg. 56840 (1978).

236. Supra note 230 . 


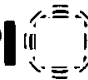

237. 16 U.S.C. $\$ \$ 1451-64$ (1976).

238. See 9 Environ. Rep. (BNA) 1416-17 (1978).

239. Id. at 1293.

240. Pub. L. No. 95-217, 91 Stat. 1566, 1593-96 (1977).

241. 33 U.S.C. \$ 1321 (1976).

242. Pub. L. No. $94-265,90$ Stat. 331 (1976).

243. 33 U.S.C. \$\$ 1221-27 (1976).

244. 16 U.S.C. \$\$ 1401-34 (1976).

245. See, e.g., 42 Fed. Reg. 5964, 5966 (1977).

246. 33 U.S.C. \$S 1501-24 (1976).

247. 16 U.S.C. $1432(a)(1976)$.

248. Id. at $1432(\mathrm{~b})$.

249. Id.

250. Id. at $1432(\mathrm{c})$.

251. Id. at $1432(d)$.

252. Id. at 1432(g).

253. Id. at 1432(f).

254. See notes 134-35 supra.

255. See generally Blumm \& Blumstein, The Marine Sanctuarles Program: $\Lambda$ framework for Critical Areas Management in the Sea, 8 Env. L. Rep. (BNA) 50016 (1978).

256. Id.

257. See'generally Comment, Renewed Controversy Over the International Reach of NEPA, 7 Envt' L. Rep. 10205 (1977); Sierra Club v. A.E.C., 4 id. at 20685 (D.D.C. 1974); Environmental Defense Fund, Inc. v. U.S. Agency for International Development, 6 id. at 20121 (D.D.C. 1975); Sierra Club v. Coleman, 405 F. Supp. 53(D.D.C. 1975), injunction continued 421 F. Supp. 63 (D.D.C. 1976); Council on Environmental Quality, Environmental Quality-Eighth Annual Report Appendix G395 (1977).

258. See 9 Environ. Rep. (BNA) 304 (1978).

259. Id. 
260. Id. at 305 .

261. Id. at 1049 .

262. Id.

263. Noted in Stein, Environmental Aspects of OTEC Development and Demonstration, in ASW Sturdy, supra noto 70; at 154 .

264. See Report of the U.N. Conference on the Human Environment, U.N. Doc. A/CONF.48/14/Rev. 1 (1972).

265. Id. at 5 .

266. Id.

267. Id. at 4 .

268. Supra note 153.

269. Supra note 156 .

270. Reprinted in 14 Int 1 Legal Materials 959 (1975).

271. In addition to note 168 supra, see generally 4 New Directions in the Law of the Sea, supra note 10 , at $331-518 ; 6$ id. at 456-562; Hickery, Jr., Custom and LandBased Pollution of the High Seas, 15 San Diego L. Rev. 409, 445-54 (1978); Okidi, note 167 supra.

272. ICNT art. 193.

273. See id. arts. 195(2), 238.

274. Id. art. 195(1).

275. Id. art. 195(3)(a)(iii).

276. Id. art. 195(3)(b).

277. Id. art. 195(3)(d).

278. ㅁ‥ art. 196.

279. Id. art. 205.

280. Id. art. 207.

281. Id. art. 236(1).

282. For a critical appraisal of ICNT provisions on the marine environment, see Schneider, Something Old, Something New: Some Thoughts on Grotius and the Marine Environment, $18 \mathrm{Va.} \mathrm{J.} \mathrm{Int'l} \mathrm{L.} 147$ (1977). 


\section{See Section I supra.}

284. OTEC operations might have implications for' antitrust laws, for the large investment needed for the construction, purchase or operations of an OTEC plant might require the involvement of several firms and/or states. Similarly, a joint venture may be an attractive vehicle to market OTEC Technology and/or OTEC energy. For a discussion of some of the issues raised by joint arrangement for developing new technology or producing new products, see Baker, Antitrust as a Spur to Technical Progress, 23 Am. U. L. Rev. 547 (1974).

285. See generally Faron, supra note 165, at 107-11; Nyhart, Problems of Legal Responsibility and Liability to Be Anticipated in OTEC Operations, in Knight, Nyhart \& Stein, supra note 9, at 129-64.

286. It is proposed that the Federal Energy Regulatory Commission, as the lead federal agency, assume responsibility for formulating and implementing the needed "utility policy" regarding OTEC.

287. See generally sources cited in note 205 supra; B. Washom \& J. Nilles, supra note 9.

288. A Senate Resolution, S.49, was introduced in 1978 urging the United States "to negotiate an international treaty requiring environmental impact assessments on major projects that could harm the environment of another nation or the global commons. International impact statements could be filed with the ... (UNEP)." The Resolution would require states parties to the treaty to "consult with affected nations, or with the UNEP in cases involving global commons, to minimize harmful impacts across international boundaries." 9 Environ. Rep. (BNA) 539 (1978). 